\title{
Cnoidal waves and bores
}

BY

\author{
J.A. SANDOVER, \\ B.SC., PH.D., D.1.C., A.M.I.C.E., A.C.C.I.
}

$\Lambda \mathrm{ND}$

(French text, p. 456)
C. TAYLOR, B.SC., PH.D. out in a channel $60 \mathrm{ft}$, long, the sides of which could be set to any desired slope to the vertical. The agreement between the experimental and theoretical results, was reasonable but not so good as when the results for a rectangular channel are compared. The major difference in the results for the trapezoidal channel was that whilst the actual lateral crest profile of the waves was curved, the theoretical lateral profile, due to the drastic simplifications in the theory, was a straight line.

The theoretical analysis and comparison of the results form the subject of this contribution. In addition, the results are shown in nondimensional form, thus allowing for extram polation to larger channels.

\section{INTRODUCTION}

If a relatively small discharge of fluid is suddenly initiated at one end of an open channel into a depth of still water an undular surge wave is formed : the longitudinal profile of such a bore, in a rectangular channel, is indicated in Figure $1 a$.

As such a disturbance proceeds downstrearn, the number of undulations increases, and in addition, the crest height of each undulation increases rapidly, whilst the bore travels a relatively short distance and then decreases steadily because of the effects of friction. When the initial discharge exceeds a certain limiting value which depends on the dimensions, shape and roughness of the channel and upon the initial depth of water, the leading undulation attains a maximum height breaks, Figure $1 b$. The broken water disappears as the surge continues to move along the channel and, if the initial discharge is large enough, the wave builds up to breaking again. This is repeated along the length of the channel, until the effective discharge at the head of the bore is reduced by friction to a value less than the limiting value. Then, the leading wave no longer breaks but as before the amplitudes increase rapidly to a maximum and thereafter decrease steadily. At an even greater initial discharge the bore will appear as a steep fronted mass of water, Figure $1 c$, resembling a moving hydraulic jump, which will also pass through the phases of a breaking undular and an undular bore as the effective discharge at the head of the wave is reduced by friction. This phenomena has already been described by Favre [4] and by the authors $[10]$ when the bores are formed in rectangular channels. Further experimental work has since been carried out $[13]$, to determine the profiles of undular surge waves in prismoidal channels and the previous theoretical analysis, with certain modifications, has been extended to this problem. The undulations, 

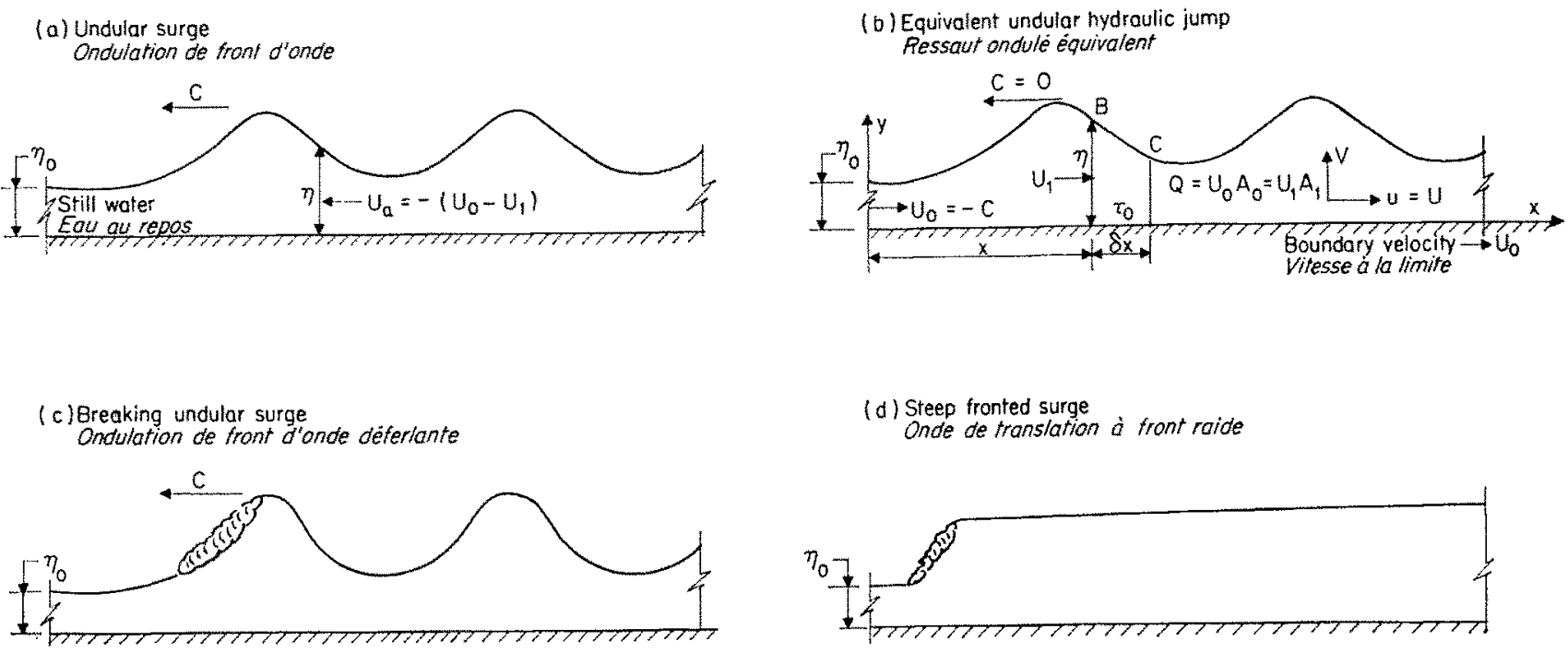

(d) Steep fronted surge

Onde de trans/ation di front raide

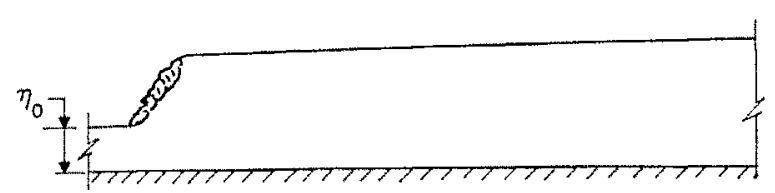

Fig. 1.

If a velocity $(-c)$ equal and opposite in sign to the velocity of the leading wave of the undular surge is imposed on system $(a)$, it will reduce to system $(b)$.

L'imposition d'une célérité (-c) de valeur égale et de signe opposé à celui de la célérité de la première ondulation dil front d'onde, sur le système (a), réduira celui-ci au système (b).

however, no longer have the regular forms of Figure $1 a$, except at a very low discharge, since as would be expected, the waves tend to break at the walls of the channel, where the depth is in effect zero, This incidentally, is termed the breaking of the "side waves". The theoretical analysis is therefore of even more restricted value than in rectangular channels, where the agreement between theoretical and practical results was excellent except where the wave amplitude was near to the limit of breaking. This covered a range of values of maximum depth to undisturbed depth of $1: 1.75$ approximately, whereas in prismoidal channels this ratio is only $1: 1.5$ approximately when the side slope is $30^{\circ}$ to the vertical and $1: 1.3$ at a $60^{\circ}$ side slope. On the other hand, the change in wave height was not so marked when the side waves broke as when the complete wave broke in either the rectangular channel or in the prismoidal channel.

Another and very interesting difference was the variation in the depth under the wave crest across a prismoidal channel, which is clearly indicated in Figure 7 and 9. This, unfortunately, was not predicted theoretically since one of the assumptions was that the lateral velocity components were negligible. Finally, secondary "fish-tailed" waves were observed, due presumably, to the lateral flow effects and at a $60^{\circ}$ side slope these waves obscured the main wave pattern.

\section{THEORETICAL ANALYSIS}

Serre [12] and independently, Benjamin and Lighthill [2] demonstrate that a stable undular surge wave is theoretically possible and that the wave form in two dimensional flow can be represented to a good approximation by the graph of the square of Jacobean elliptic function, cn $x$. The profiles, of the wave forms have been determined experimentally and a comparison has been made between the theoretical and experimental results [10]. This comparison is now extended to the results obtained in prismoidal channels. In order that the equations governing this motion should not be dependent on time, a velocity equal and opposite to the velocity of propagation of the leading wave is imposed on the system. This reduces the flow to the steady state and the surge becomes equivalent to a hydraulic jump, Figure 1, but with moving boundaries.

Using the momentum equation an expression can be obtained in terms of known quantities for the slope of the water profile at a distance from the origin and from this information the wave profile can be determined using a step by 
step process. Referring to Figure 1, and taking a control surface bounded by the $y$ ordinates at $B$ and $C$, the channel bed and the free surface; assuming that the velocity distribution is uniform across the section, that the channel bed is horizontal, the flow is incompressible and that all the friction effects are confined to the boundary layer, the momentum equation in the $x$ direction can be expressed as:

$$
\begin{aligned}
\iint_{\mathbf{B}} \frac{p}{\rho g} d \mathbf{A} & +\frac{\mathrm{QU}_{\mathrm{B}}}{g}-\iint_{\mathrm{C}}^{2} \frac{p}{\rho g} d \mathrm{~A}-\frac{\mathrm{QU}_{\mathrm{O}}}{g} \\
& =-\frac{\tau_{0}}{\rho g}(b+2 \eta \sec 0) \partial x
\end{aligned}
$$

where :

$p$ represents the local pressure;

$Q$ represents the mean steady state velocity charge:

(I) represents the mean steady state velocity at the section;

$\eta$ represents the depth at this section;

$\theta$ represents the angle between the sides of the channel and the vertical;

$\tau_{0}$ represents the boundary shear stress.

and suffices $B$ and $C$ refer to the appropriate section.

This expression can be solved and the free surface profile determined if further simplifying assumptions are made. First, the momentum function:

$$
\mathrm{M}=\iint \frac{p}{\rho g} d \mathrm{~A}+\frac{\mathrm{QU}}{g}
$$

must be determined. As an appreciable curvature of the fluid elements can exist the pressure distribution cannot be assumed to be hydrostatic and must be determined from the Eularean dynamic equation.

$$
\frac{\varphi g}{1} \frac{\partial p}{\partial y}=-1-\frac{v}{g} \frac{\partial v}{\partial y}-\frac{u}{g} \frac{\partial v}{\partial x}-\frac{w}{g} \frac{\partial v}{\partial z}
$$

where $u, v$ and $w$ are the velocity components in the $x, y$ and $z$ directions respectively. Two arbitrary simplifications have now to be made: that the lateral velocity component is negligible when compared with the $x$ and $y$ components and that the velocity distribution is assumed to be uniform, i.e. $u=U$ (the mean velocity of the flow in the $x$ direction). At small values of the side slope $\theta$, it is evident that the first assumption can be justified, but for the assumption of a uniform velocity distribution to be approximately valid, the flow must be turbulent, the side slope and the wave amplitude must be small. A preliminary approach was therefore attempted without employing these simplifica- tions but the resulting equations were so complex that it was considered that they were practically insoluble unless a drastic series of assumptions were made. It was therefore thought preferable to make the above assumptions at this early stage in the analysis of the problem. That there is little justification for either of these assumptions when the side slope of the channel is greater than $45^{\circ}$ to the vertical is evident from a consideration of Figure 11. Since, however, in practice it is unlikely that the side slope would exced this figure the theoretical results are of some value when the side waves do not break. Once this occurs, the theoretical approach is immeasurably more complex and recourse has to be made to experimental results.

In order that equation 3 may be integrated, $v, u, \partial v / \partial y$ and $\partial v / \partial x$ must be determined. Therefore, referring to Figure 2, since

$$
u=\mathrm{U}=\frac{\mathrm{Q}}{r_{\mathrm{i}}(b+\eta \tan 0)}
$$

where $\eta$ is the local depth of water; then,

$$
\frac{d u}{d x}=-\frac{\mathrm{Q}(b+2 \eta \tan \theta)}{\eta^{2}(b+\eta \tan \theta)^{2}} \frac{d \eta}{d x}
$$

Further, since the equation of continuity is:

$$
\frac{\partial u}{\partial x}+\frac{\partial v}{\partial y}=0
$$

and if it is assumed that $u$ is a function of $x$ only (this is a most restrictive assumption and is responsible for the major portion of the discrepancies between theoretical and practical results).

$$
\frac{\partial u}{\partial x}=\frac{d u}{d x}
$$

whence:

$$
\frac{\partial v}{\partial y}=+\frac{\mathrm{Q}(b+2 \eta \tan \theta)}{\eta^{2}(b+\eta \tan \theta)^{2}} \frac{d \eta}{d x}
$$

If this expression is integrated with respect to $y$ :

$$
v=+\frac{\mathrm{Q}(b+2 \eta \tan \theta)}{\eta^{2}(b+\eta \tan \theta)^{2}} \frac{d \eta}{d x} y
$$

since when $y=0, \quad v=0$ and therefore the constant integration is zero. This equation is then differentiated with respect to $x$, i.e.

$$
\begin{aligned}
& \frac{\partial v}{\partial x}=\frac{\mathrm{Q}(b+2 \eta \tan \theta)}{\eta^{2}(b+\eta \tan \theta)^{2}} y \frac{d^{2} \eta}{d x^{2}} \\
& -2 \mathrm{Q}\left[\frac{b^{2}+3 b \eta \tan \theta+3 \eta^{2} \tan ^{2} \theta}{\eta^{3}(b+\eta \tan \theta)^{3}}\right] y\left(\frac{d \eta}{d x}\right)^{2}
\end{aligned}
$$


The pressure gradient in the $y$ direction (equation 3) can now be expressed in terms of $Q, \eta, b, x$ and $\theta$, and if this expression is integrated with respect to $y$ :

$$
\begin{array}{r}
\frac{p}{\rho g}=(\eta-y)-\left[\frac{\mathrm{Q}^{2}\left(\eta^{2}-y^{2}\right)}{2 g \eta^{3}(b+\eta \tan \theta)^{3}}\right] \\
{\left[\left(\frac{b^{2}+2 b \eta \tan \theta+2 \eta^{2} \cdot \tan ^{2} \theta}{\eta(b+\eta \tan \theta)}\right)\left(\frac{d \eta}{d x}\right)^{2}\right.} \\
\left.--(b+2 \eta \tan \theta) \frac{d^{2} \eta}{d x^{2}}\right]
\end{array}
$$

Then again referring to Figure 2, the area of the hatched elementary strip:

$$
\delta \mathrm{A}=b \delta y+2 y \tan 0 \delta y
$$

and since $x$ and $\gamma_{j}$ are constant, equation 4 can be expressed as:

$$
\frac{p}{9 g}=f(y)
$$

Therefore equation (2) can be rewritten as: $\mathrm{M}=\int_{0}^{\eta} f(y)(b+2 y \tan \theta) d y+\frac{\mathrm{Q}^{2}}{g_{\eta}(b+\eta \tan \theta)}$

and if the integration of equation (4) is carried out with respect to $y$, equation (5) can be rewritten:

$$
\frac{d^{2} \eta}{d x^{2}}-\varphi_{1}(\eta)\left(\frac{d \eta}{d x}\right)^{2}-\varphi_{2}(\eta)=0
$$

where:

$$
\varphi_{1}\left(r_{i}\right)=\frac{1}{\eta}\left[\frac{b^{2}+2 \eta b \tan \theta+2 \eta^{2} \tan ^{2} \theta}{(b+\eta \tan \theta)(b+2 \eta \tan \theta)}\right](7)
$$

and:

$$
\begin{aligned}
& \varphi_{2}(\eta)=\left[\frac{12 g(b+\eta \tan \theta)^{3}}{\mathrm{Q}^{2}(3 \eta \tan \theta+4 b)(b+2 \eta \tan \theta)}\right] \\
& {\left[\mathrm{M}_{r}-\frac{\eta^{2}}{6}(3 b+2 \eta \tan \theta)-\frac{Q^{2}}{g \eta_{1}(b-\eta \tan \theta)}\right]}
\end{aligned}
$$

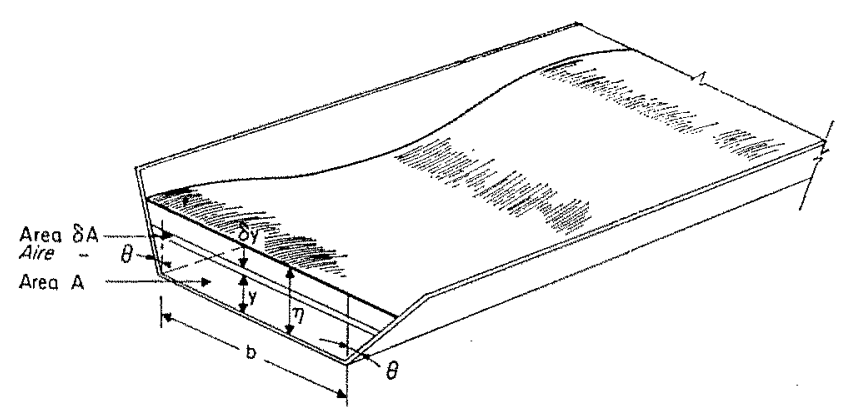

Fig. 2. (which is the differential form of equation (2)).

If equation (6) is solved, assuming that $\mathbf{M}_{x}$ is constant, it can be demonstrated that the solution represents the profile of a solitary wave. This result implies that the boundary shear stress in equation (1) is zero, and if this is so there will not be any change in the shape of this wave as it proceeds down the channel. This is not to say, however, that a solitary wave form cannot exist in a real channel where friction effects exist. This phenomenon has been investigated with considerable success by various workers [5]. Benjamin and Lighthill [2] show that a stationary solitary wave is the only disturbance that can be formed in an open channel from a uniform steady stream without changes in momentum or energy and that if changes occur, the profile of the disturbance will be undular. This statement of Benjamin and Lighthill, however, is not a contradiction of the previous remark, that a solitary wave can exist in a real channel, because such a solitary wave is, in reality, the leading undulation of an undular bore. These workers also show that the linearised theory of Lemoine [7] cannot be applied to an undular surge, since the individual wavelengths and amplitudes are too great. In fact, the only possible wave that can occur, if the profile is sinusoidal as Lemoine assumes, is a solitary wave.

It is therefore evident that the effects or wall friction must he investigated.

\section{Boundary Friction}

Equation (1) can be re-phrased in the form:

$$
\mathrm{M}_{x}-\mathrm{M}_{(x+\delta x)}=-\frac{\tau_{0}}{\rho g}(b+2 \eta \sec \theta) \delta x
$$

or:

$$
\frac{d \mathrm{M}}{d x}=+\frac{\tau_{0}}{\rho g}(b+2 \eta \sec \theta)
$$

Assuming a skin friction coefficient:

$$
c_{f}=2 \tau_{0} / \rho \mathrm{U}_{m}^{2}
$$

where the Chezy roughness coefficient:

$$
\mathrm{C}=\left(2 g / c_{f}\right)^{1 / 2}
$$

and evidently from Figure 1 ,

$$
\mathrm{U}_{m}=--\left(\mathrm{U}_{a}\right)=\mathrm{U}_{0}-\mathrm{U}_{1} \text {, }
$$

therefore: 


$$
\begin{aligned}
& \frac{d \mathrm{M}}{d x}=\frac{\mathrm{Q}^{2}(b+2 \eta \sec \theta)}{\mathrm{C}^{2}} {\left[\frac{1}{\eta_{0}\left(b+\eta_{0} \tan \theta\right)}\right.} \\
&\left.-\frac{1}{\eta(b+\eta \tan \theta)}\right]_{2}
\end{aligned}
$$

where the suffix 0 refers to undisturbed conditions.

Equation (6) could then be rewritten:

$$
\frac{d^{2} \eta}{d x^{2}}-p_{1}(\eta)\left(\frac{d \eta^{2}}{d x}\right)-\varphi_{3}\left(\eta, \mathrm{M}_{x}\right)=0
$$

The solution of this equation, in terms of $\eta$ and $x$, would represent the longitudinal profile of a bore or surge wave in a prismoidal open channel. This analysis is only effective if the waves forming the bore have not broken and if $C$ can be determined.

Therefore an expression for the slope of the surface profile in a prismoidal channel in gradually varied flow was determined, i.e.

$$
\frac{d \eta}{d x}=\left[\frac{\mathrm{Q}_{f}^{2}(b+2 \eta \sec \theta)}{\mathrm{C}^{2} \eta^{3}(b+\eta \tan \theta)^{3}}\right]\left[\frac{1}{1-\frac{\mathrm{Q}^{2}}{g \eta^{3}} \frac{(b+2 \eta \tan \theta)}{(b+\eta \tan \theta)^{3}}}\right]
$$

where $Q_{f}$ is the discharge.

A series of gradually varied flow regimes were initiated in the model channel and $C$ evaluated at the position in the channel, where the surges were to be recorded, for varying values of depth $\eta$, determined by the height of a weir gate at the outlet to the channel, and at varying discharges $Q_{f}$. These values of $C$ were then plotted against an equivalent value of Reynold's number $r$, where

$$
r=\vee \mathcal{R}_{\mathrm{N}}=\mathrm{U} m=\frac{Q_{f}}{(b+2 \eta \sec 0)}
$$

In this expression $m$ is the hydraulic mean radius of the flow and $v$ is the kinematic viscosity of the liquid. It was then assumed that if $r$ could also be determined for different depths of flow in the surge wave, then the appropriate value of $C$ could be read directly from the curves of C: $r$, i.e. dynamic similarity had been established. In order that this may be carried out, however, the relationship between $Q, Q_{a}$ and $Q_{\text {; }}$ must be established, where $Q_{a}$ is the actual discharge initiating the surge wave.

$\mathrm{Q}$ is determined from the relationship, where $c$ is the velocity of the bore, which can be determined experimentally and:

$$
\mathrm{U}_{u}=-\left(\mathrm{U}_{0}-\mathrm{U}_{1}\right)
$$

then,

$$
\begin{gathered}
\mathrm{Q}_{a}=-\left(\mathrm{U}_{0}-\mathrm{U}_{1}\right) \mathrm{A}_{1} \\
=\mathrm{Q}\left[\frac{\eta(b+\eta \tan \theta)}{\eta_{0}\left(b+\eta_{0} \tan \theta\right)}-1\right]
\end{gathered}
$$

Now $r$ at section 1, Figure 1, under the wave is :

$$
r=\mathrm{U}_{0} m=\frac{\mathrm{Q}_{a}}{\mathrm{~A}}=\frac{\mathrm{Q}_{a}}{b+2 \eta \sec \theta}
$$

Whence, $\mathbf{Q}_{a}$ must be equal to $Q_{f}$ for dynamic similitary. Therefore for any bore velocity $c$, $Q$ can be determined and hence $Q_{a}$ and $r$ for any depth $\eta$. Then from the curve of $\mathrm{C}: r, \mathrm{C}$ can be determined for the appropriate value of $\mathrm{Q}_{f}$ which is equal to $\mathrm{Q}_{a}$.

To assist in the calculations, two further families of curves were drawn, Figure $3 b$ and $3 c$, of $\eta: r$ and $\eta: Q_{u}$ according to the relationship expressed in equations (15) and (16) respectively. If $Q$ and $\eta$ are known, $Q_{a}$ can be determined from Figure $3 c$, and $r$ from Figure $3 b$. Then, $Q_{a}$ is equal to $Q_{f}$ and $C$ can be determined from Figure $3 a$.

It is realised that the method used in the determination of $\mathrm{C}$ is open to criticism, particularly since the flow at the head of the surge must be laminar, and it is hoped that further investigations will determine whether an
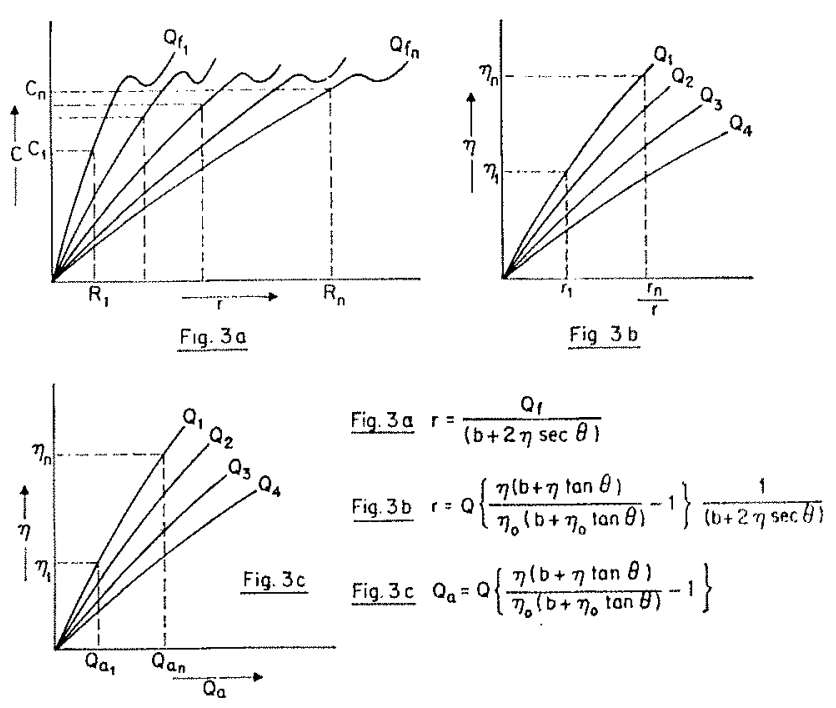

Fiq. 3.

$$
\mathrm{Q}=c \mathrm{~A}_{0}=\mathrm{U}_{0} \mathrm{~A}_{0}
$$


approach can be made by means of the boundary layer theory. In practice, the method already used would be impossible since a designer would require the data before the channel was constructed, but it has been observed that the larger the channel, the more nearly the value of $C$ approaches the empirical value obtained from an expression such as the Manning formula. In a full scale channel, therefore, it is likely that a mean value of $\mathrm{C}$ obtained by this means could be used. The justification for this method of determining the skin friction is that is has given such good results when computing surge wave profiles in rectangular channels.

\section{Solution of Equation 12}

The equivalent equation (21) for rectangular channels can be solved by an extremely laborious step by step method using a desk calculator [10], but this could not be applied to the solution of equation (12) without an unwarranted expenditure of time and labour. A digital compunter was used instead, employing the Runge Kutta $[3,8]$ step by step method of numerical analysis of differential equations of the first order. The equation to be solved:

$$
\frac{d^{2} \eta}{d x^{2}}=\varphi_{1}(\eta)\left(\frac{d \eta}{d x}\right)^{2}+\varphi_{3}(\eta, \mathrm{M})
$$

can be reduced to three simultaneous first order differential equations:

$$
\begin{aligned}
& \frac{d \eta}{d x}=\zeta=F_{1}(\zeta, \eta, M) \\
& \frac{d \zeta}{d x}=\varphi_{1}(\eta) \zeta^{2}+\varphi_{3}(\eta, M)=F_{2}(\zeta, \eta, M)
\end{aligned}
$$

and from equation (11),

$$
\frac{d \mathrm{M}}{d x}=\varphi_{4}(\eta, \mathrm{C})=\mathrm{F}_{3}(\zeta, \eta, \mathrm{M})
$$

where $\varphi_{1}, \varphi_{3}$ and $\varphi_{4}$ are known functions.

If initial values of $\eta$, $\zeta$, and $M$ are known, and if curves of these variables are plotted as ordinates in three planes against $x$ as abscissa, the slopes of the curves are obtained from these three equations. Using these slopes and a value of $x=x_{0}+\delta x$, new values of slope can be determined and this process can be repeated continuously, $\eta$ being calculated from a knowledge of $\delta x$ and $d \eta / d x$. Thus, the profile of the bore is obtained.
This profile is undular and can be represented approximately by the graph of the Jacobean elliptic $c n$ function. There is no allowance in this theory for the effects of the waves breaking and therefore the waves would appear to increase in amplitude indefinitely. In practice, if the discharge is above a certain limiting value, the leading wave breaks, energy is lost in turbulence and hence, as shown by Benjamin and Lighthill, the amplitude decreases as the energy loss increases. This causes a reduction in the leading wave celerity and since the velocity of the second wave is not decreased, the first trough tends to be filled with water. Thus, at large discharges, the hollows are completely filled and the bore is steep fronted with a practically straight line profile.

One practical difficulty was encountered in the calculations since $d \eta / d x=\zeta=0$. when $x=0$. In the theory of the solitary wave it can be demonstrated that if $\eta_{0}$ is increased by an amount $\Delta \eta$, this results in a change in $x$ from 0 to $\infty$. Therefore for the first value of $\Delta \eta$ it was discovered, by trial and error, that $\zeta$ should be $0.001 \mathrm{rdn}$. The horizontal step length $\Delta x$ was 0.05 inches and this value again was determined as the optimum value by a trial and error procedure. Unfortunately it was not possible to use a variable value of $C$ in the compunter employed and a mean value had to be used. This necessitated a trial computation of $\mathrm{C}$ for increments of $\Delta \eta=0.1$ inches, assuming a maximum value of $\eta$. The arithmetic mean value of $C$ was determined and the surge profile calculated. If the resulting value of $\eta_{\max }$ differed from the estimated value, the process was repeated until an approximately correct value of $\eta_{\max }$ was assumed.

Briefly, the practical details of the solution of equation (12) are as follows:-

$$
\frac{d \zeta_{p}}{d x}=\varphi_{1}(\eta) \zeta^{2}+\varphi_{2}(\eta)
$$

$\eta_{0}$ is known, $Q$ can be determined experimentally or in practice by Favre's method [4] and $\zeta_{0}$ is assumed to be $0.001 \mathrm{rdn}$. The functions $\varphi_{1}$ and $\varphi_{2}$ can be determined from equations (7) and (8) if $\mathbf{M}_{n}$ is known, and the initial value of the momentum function,

$$
\mathrm{M}_{y=0}=\frac{\eta_{0}{ }^{2}}{6}\left(2 \eta_{0} \tan \theta+3 b\right)+\frac{\mathrm{Q}^{2}}{g \eta_{0}(b+\eta \tan \theta)}
$$

Finally, the calculation "step-length",

$$
x=0.05 \text { in }
$$

is chosen. Then:

a) $\zeta=0.001=(d \eta / d x)$ and since $\Delta x=0.05$, a new value of $\eta_{1}$ can be determined $\eta_{1}$; 
b) Equation (11) is solved using $\eta_{1}$ to obtain a value of $d M / d x$. Again knowing $\Delta x$, the change in momentum, $\Delta \mathrm{M}$, can be calculated; then $\mathrm{M}_{0}+\Delta \mathrm{M}=\mathrm{M}_{1}$.

c) Equation $(17 b)$ is solved for $\zeta$ using the value of $\mathrm{M}_{1}=\mathrm{M}_{x}$.

d) Items $(a)$ to $(c)$ are repeated, and the corresponding values of $\eta$ and $x$ are plotted graphically.

\section{Cnoidal Bores in Rectangular Channels}

It can be shown that a similar expression to equation (12) can be obtained, in prismoidal channel flow, if the energy equation is used but the values of $\varphi_{1}, \varphi_{3}$ and $\varphi_{4}$ are different. If a similar analysis is carried out for a rectangular channel [10]. i.e. if $\theta$ in the previous equations is made equal to zero, two similar but simplified expressions for momentum, M, and energy $H$ are obtained. These two expressions can then be combined, resulting in:

$$
\frac{\mathrm{Q}^{2}}{6 g b^{2}}\left(\frac{d \eta}{d x}\right)^{2}=\mathrm{H} \eta^{2}-\frac{\eta_{i}^{3}}{2}+\frac{\mathrm{Q}^{2}}{2 g b^{2}}-\mathrm{M}_{\eta}
$$

and the changes in momentum and energy are determined from the following expressions:

$$
\begin{aligned}
& \frac{d \mathrm{M}}{d x}=\frac{\mathrm{Q}^{2}}{\mathrm{C}^{2} b^{3}}\left(\frac{1}{\eta_{0}}-\frac{1}{\eta}\right)^{2}\left(b+2 \eta_{1}\right) \\
& \frac{d \mathrm{H}}{d x}=\frac{\mathrm{Q}^{2}}{\mathrm{C}^{2} b^{2} \eta}\left(\frac{1}{\eta_{0}}-\frac{1}{\eta}\right)^{2}(b+2 \eta)
\end{aligned}
$$

Depth increments $(\Delta \eta)$ were used in these calculations instead of increments in $x$. Starting with the initial values of $H$ and $M$ but assuming the depth is $\eta_{0}+\Delta \eta$ a value of $d \eta / d x$ can be obtained and also the value of $\Delta x$. The incremental changes in $H$ and $M$ can be calculated and these used with the value of $\eta_{0}+2 \Delta \eta$ to obtain new values of $d \eta / d x$, etc.

Since the above expressions were cumbersome they were replaced with the equivalent nondimensional forms, i.e. equation (8) becomes

$$
\frac{1}{6}\left(\frac{d \mathrm{Y}}{d \mathrm{X}}\right)^{2}=\mathrm{H}^{\star} \mathrm{Y}^{2}-\frac{\mathrm{Y}^{3}}{2}+\frac{1}{2}-\mathrm{M}^{\star} \mathrm{Y}
$$

where:

$$
\begin{aligned}
\mathrm{Y} & =\eta / \eta_{\text {critical }}, \\
\mathrm{H}^{\star} & =\mathrm{H} / \eta_{\text {critldul }}
\end{aligned}
$$

and :

$$
\mathrm{M}^{\star}=\mathrm{M} / \mathrm{r}^{2}{ }_{\mathrm{crticn}}
$$

To assist in the calculations these expressions were modified yet again, and equation (21) becomes:

$$
\begin{aligned}
& \frac{1}{6}\left(\frac{d \mathrm{Y}}{d \mathrm{X}}\right)_{n}^{2}=\frac{(n+1)^{2}(\Delta \mathrm{Y})^{2}\left(1-\mathrm{Y}_{0}\right)^{3}}{2 \mathrm{Y}_{0}^{2}} \\
& -\frac{(n+1)^{3}(\Delta \mathrm{Y})^{3}}{2}+\Sigma \Delta \mathrm{H}^{*} \cdot \mathrm{Y}_{n}^{2}-\Sigma \Delta \mathrm{M}^{*} \mathrm{Y}_{n}
\end{aligned}
$$

where $n$ is the step or process number in the calculation, $\Sigma \Delta H^{\star}$ is the sum of the energy terms and $\Sigma \Delta M^{*}$ the sum of the momentum terms.

These theoretical profiles were almost identical with those obtained experimentally since the assumptions made were less at variance with actual conditions than those used in the derivation of similar equations for prismoidal channels. Reverting to these latter expressions, it was not possible to combine the momentum and energy equations into one elegant expression such as equation (18). In consequence, a second order differential has to be solved which further complicates the calculations.

\section{EXPERIMENTAL INVESTIGATIONS}

A $60 \mathrm{ft} .(18.3 \mathrm{~m})$ model channel, Figure 4, was constructed with a glass base bedded in mastic on a mild steel channel section and with walls of perspex fixed to aluminium angle sections, which in turn were hinged to the mild steel base section. The rectangular cross-section of the channel was $12 \times 12$ in. and a rubber seal behind the hinges ensured that the channel remained water tight at any inclination of the walls to the vertical. In addition the height of the channel supports above the floor could be regulated using screw jacks and the channel set to any desired longitudinal slope, to a maximum of 0.01 . In the experiments, however, the channel bed was horizontal.

The inlet to the channel had to be shaped carefully to avoid the formation of secondary waves. A rectangular box section was cons- 


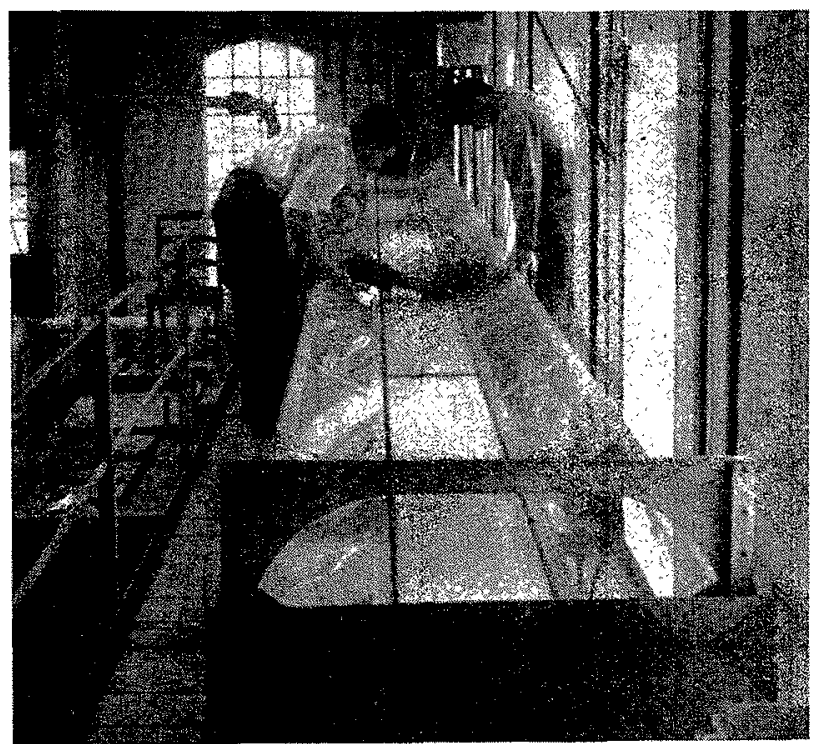

FIG. 4. .

Prismoidal channel, $60 \mathrm{ft}$ long. $\theta=60^{\circ}$. Outlet end. Canal prismatique, long de 60 pieds $(18,29 \mathrm{~m}) . \theta=60^{\circ}$. Extrémité aval.

tructed around the inlet pipes, and this inner rectangular channel was then gradually flared out to the section of the main channel.

The channel was part of a circulatory flow system and was supplied with water from a constant head tank. Bores were formed by introducing a sudden influx, controlled by a slide valve, into a still depth of water. The flow was measured using a mercury manometer, but could be pre-set approximately by the setling of a screw valve, upstream of the slide valve.

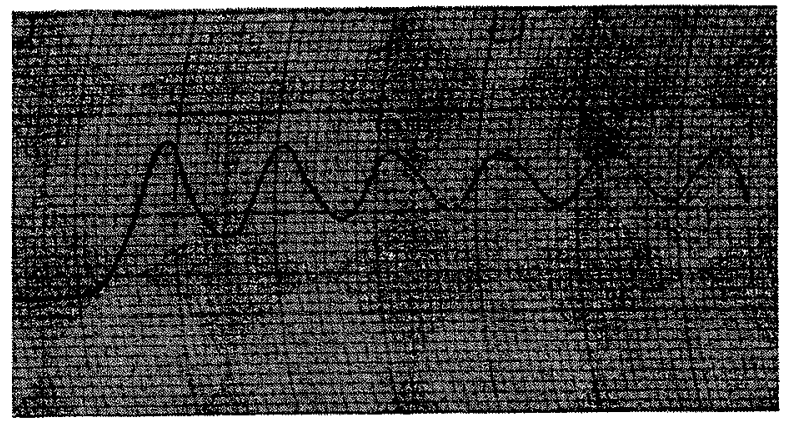

Fig. 6.

Electrical record of a typical undular surge in a rectangular channel.

Enregistrement électrique d'une ondulution de front d'onde typique. dans un canal de section rectangulaire.

Previous experiments had been carried out in a $10 \mathrm{in}$. by $5 \mathrm{in}$. rectangular, $48 \mathrm{ft}$. channel [10]. The object of the experiments was to determine the shape and the velocity of propagation of the undulations forming the surge. In a rectangular channel, since the motion is essentially two dimensional, it was only necessary to determine the longitudinal profiles and this was accomplished either photographically, Figure 5, or using capacitance type depth gauges, positioned on the centre line of the channel, Figure 6. Although the circuitry associated with the depth gauges was somewhat complex, the results were more reliable than those obtained photographically which, in consequence, were only employed as a check on the gauge results.

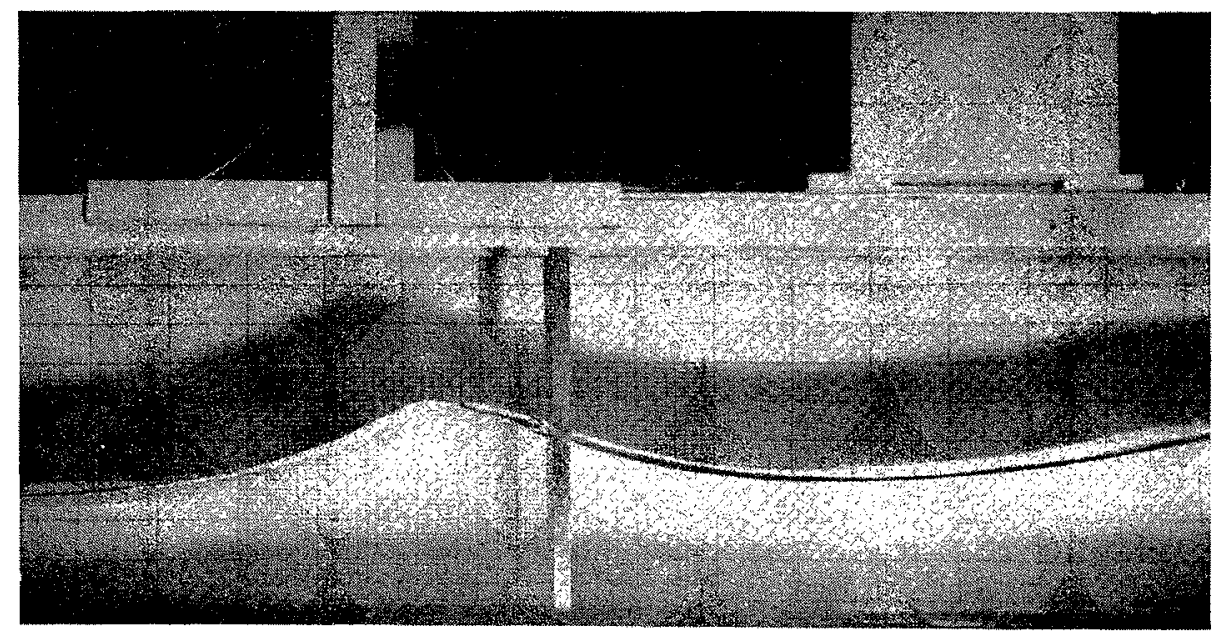

Fig. 5.

Undular surge waves in a rectangular channel. $\eta_{0}=2$ ins. Direction of motion is from right to left.

Ondulations de front donde dins un caral rectangulaire. $\eta_{0}=2$ pouces $(50,8 \mathrm{~mm}$.) Le sens du mouvement est de. droite à gauche. 
The shapes of bores in prismoidal channels are not, however, as regular, since the flow is three-dimensional. A representative bore is illustrated in Figure 7, and it can be seen that secondary waves termed "fish-tail" waves are formed on the major undulations, criss-crossing the channel. Photographic records of these waves would have been of very limited value unless a photogrammetric method, similar to that of Favre's, had been employed. Similarly, one depth gauge on the centre line would only indicate the profile on one vertical section and consequently, a number of gauges were used, spaced at equal intervals across on half of the channel section at two separate positions in the channel length [11]. From the recordings at these gauges, a three-dimensional picture of the surge and of the variation in its shape, at different values of discharge, could be built up. The recordings were repeated for various discharges, with the walls of the channel at $30^{\circ}$, $45^{\circ}$ and $60^{\circ}$, respectively, to the vertical. A static calibration was carried out before each series of tests or before each day's work began.

The velocities of propagation of the leading undulations of the surges were recorded using an on-off relay system, actuated by the wave itself; the time interval between switching on and off being marked on the paper of a pen recorder.

It was evident, from an inspection of the surges as they travelled down the channel, that for a particular initial discharge, the undulations increased in amplitude to a maximum, one after the other, and then amplitude steadily decreased. At relatively low discharges, however, and as might be expected, the undulations after increasing to a limiting depth broke at the walls, the breaking extending inwards to an extent dependent again on the magnitude of the discharge. Another point of interest, was the variation in the crest height of the undulations across the width of channel, being higher at the sides over the area of rapidly changing depth.

In addition, once the wave had broken at the edges, the crest appared as a straight line in plan, with the end angled forward but at low discharges, i.e. when the side waves did not break, the plan profile formed a curved line.

Finally, an important difference, when comparing these wave forms with those produced in rectangular channels, is the formation of the secondary "fish-tail" waves. It is thought that these must be due to the transverse flow that exists as the water level changes rapidly in a prismoidal channel. When the walls are tilted at a large angle to the vertical these secondary waves can completely obscure the primary waves.
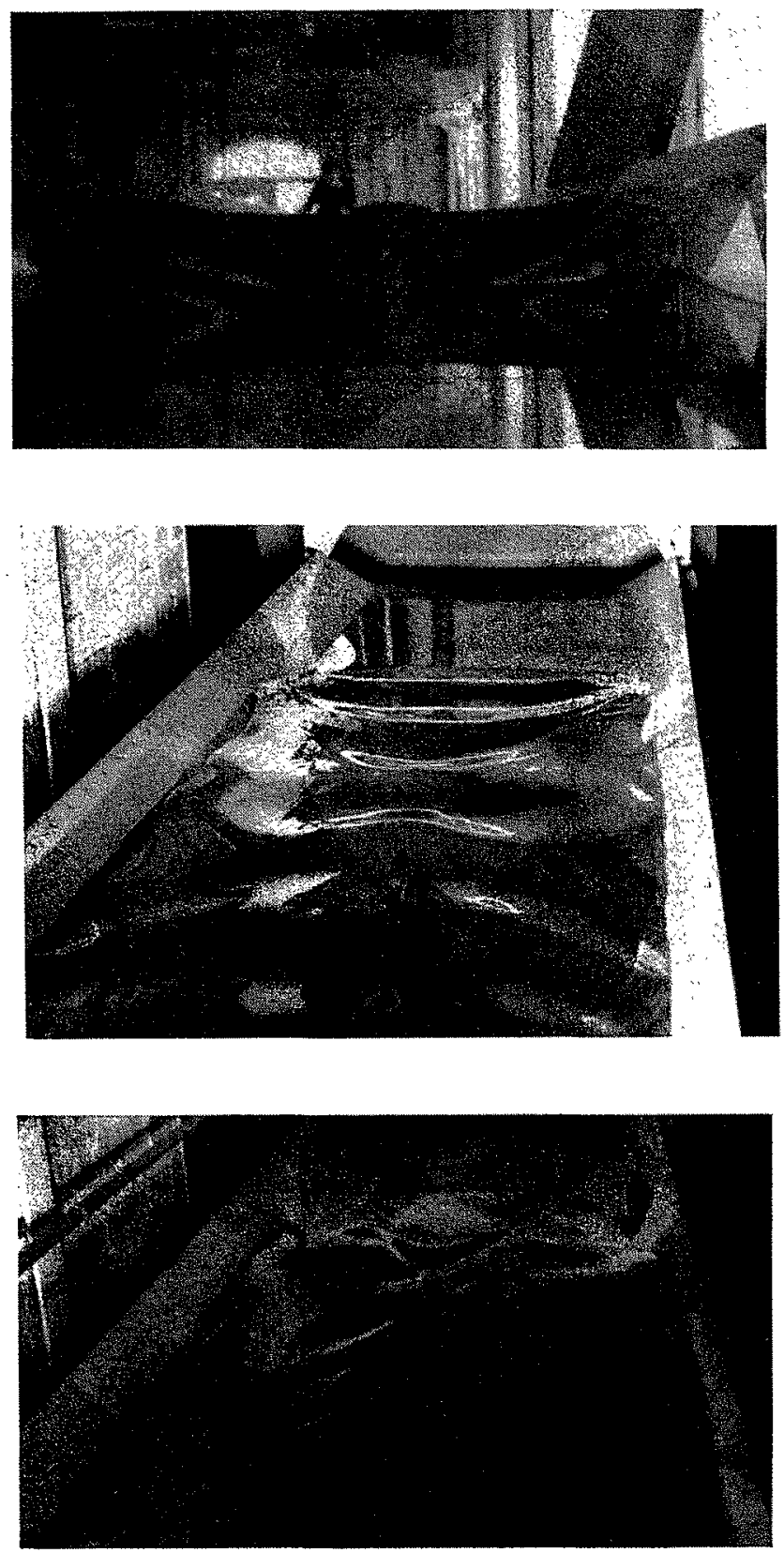

Fig. 7.

Representative surges in a prismoidal channel.

Top: Front view. Side waves just breaking. Note curvalure of crest. $\theta=45^{n}$.

Centre: Rear view. "Side waves" broken. $\theta=60^{\circ}$.

Bollom: Rear view. "Fish thil" waves evident. No breaking. $\theta=60^{\circ}$.

Ondulations de front d'onde typiques, dans un canal prismatique.

En haut: Vue de l'avant. Les ondes laterales commeneent a déferler. Remarquer la courbure de la ligne de créte. $\theta=45^{\circ}$.

Au centre: Vue de l'arrière. Les ondes latérales ont déferlé. $\theta=60^{\circ}$.

En bas: Vue the larriere. Prísence d'ondes en \&quene de poisson $*$. Aucun déferlement. $\theta=60^{\circ}$. 


\section{EXPERIMENTAL RESULTS}

A complete record of the profile of each bore was obtained, but only a limited number of measurements were taken from these records, e.g. the height of the first wave crest and trough above the bed, the first wave length and the wave velocity.

The recordings were taken at gauge positions 2 and 4 , which were 24 and 48 feet respectively from the channel inlet and the initial depth of water in all the experiments was 3 inches.

Figure $8 a$ represents the first crest and trough depth plotted against discharge, in a rectangular channel $\left(\theta=0^{\circ}\right)$, at gauge positions 2 and 4 . These curves are smooth and regular until the first crest breaks. At this discharge the previously mentioned fact of the wave refor- ming after breaking to form a smooth undular surge again is indicated by the record at gauge 4 , and by a comparison of the record at the two gauge positions. At gauge 4 (where the surge is fully formed) it is evident that a linear relationship exists; between crest heigt and discharge if the waves have not broken.

Figures $8 b, c$ and $d$, represents similar conditions at gauge position 4 , when $\theta=30^{\circ}, 45^{\circ}$, and $60^{\circ}$ respectively. The maximum wave heights are less than those in Figure $8 a$, but there are no abrupt discontinuities which characterise the recording in rectangular channels. Separate recordings were made at various positions on the cross-section of the channel and these positions are indicated on the diagram.

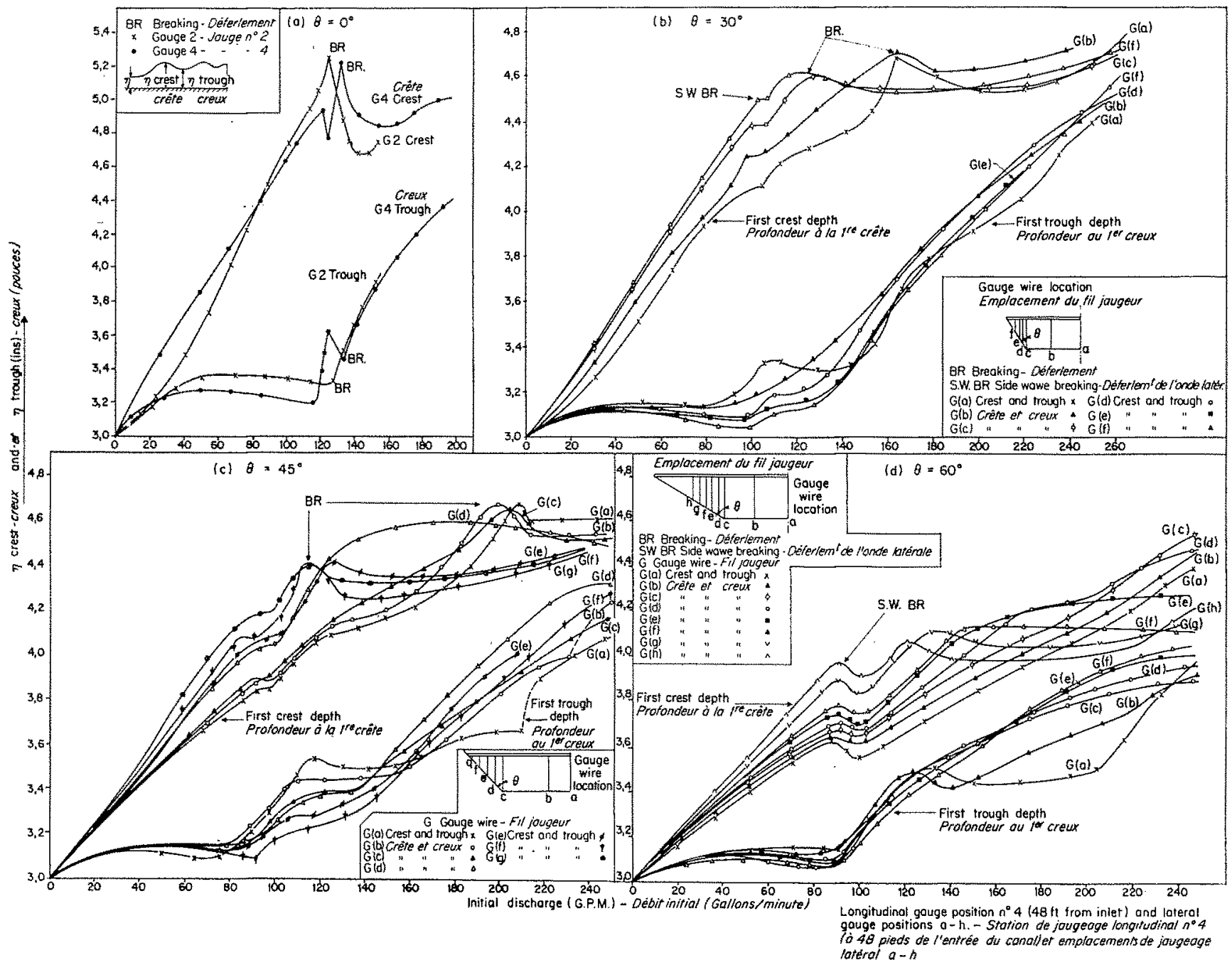

Fra. 8.

Variation of first crest and trough depth with initial discharge for different values of channel side slopes $(\theta)$.

Variation des profondeurs à la première crête, et au premier crenx, en fonction du débit initial et pour différentes inclinaisons des parois du canal $(\theta)$. 


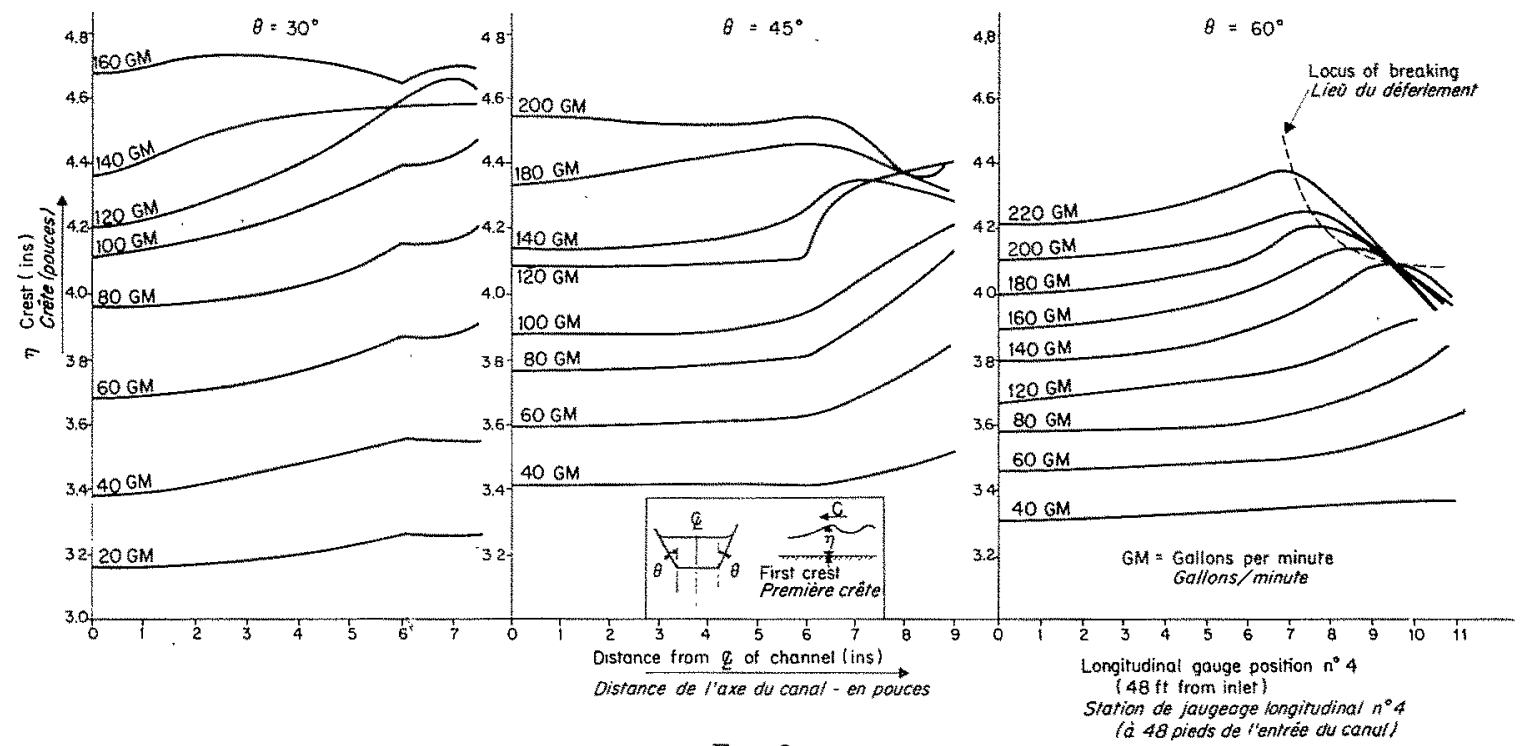

Fig. 9.

Variation in lateral first crest profile of ondular surge waves in an open channel as the side slope $(\theta)$ and the initial discharge $(Q)$ vary.

Variation, daris un profil lateral de la première crête d'tue ondulation de front d'onde dans un canal découvert, en fonction de l'inclinaison des parois ( $\theta$ ) et du debit initial $(\mathrm{Q})$.

It is evident that a linear relationship exists between the maximum wave height and initial discharge if the side waves have not broken.

Figures $9 a, b$ and $c$, are more informative pictorially, since they indicate the transverse profiles of the first crest at gauge 4 for increments of discharge and values of $\theta=30^{\circ}, 45^{\circ}$ and $60^{\circ}$. When $0=30^{\circ}$, a distinct change in curvature occurs above the junction of the bed and sides of the channel. This change in curvature disappears when the discharge is sufficicnt to cause the side waves to break and at much larger discharges the curvature is reversed. The changes in curvature before the side

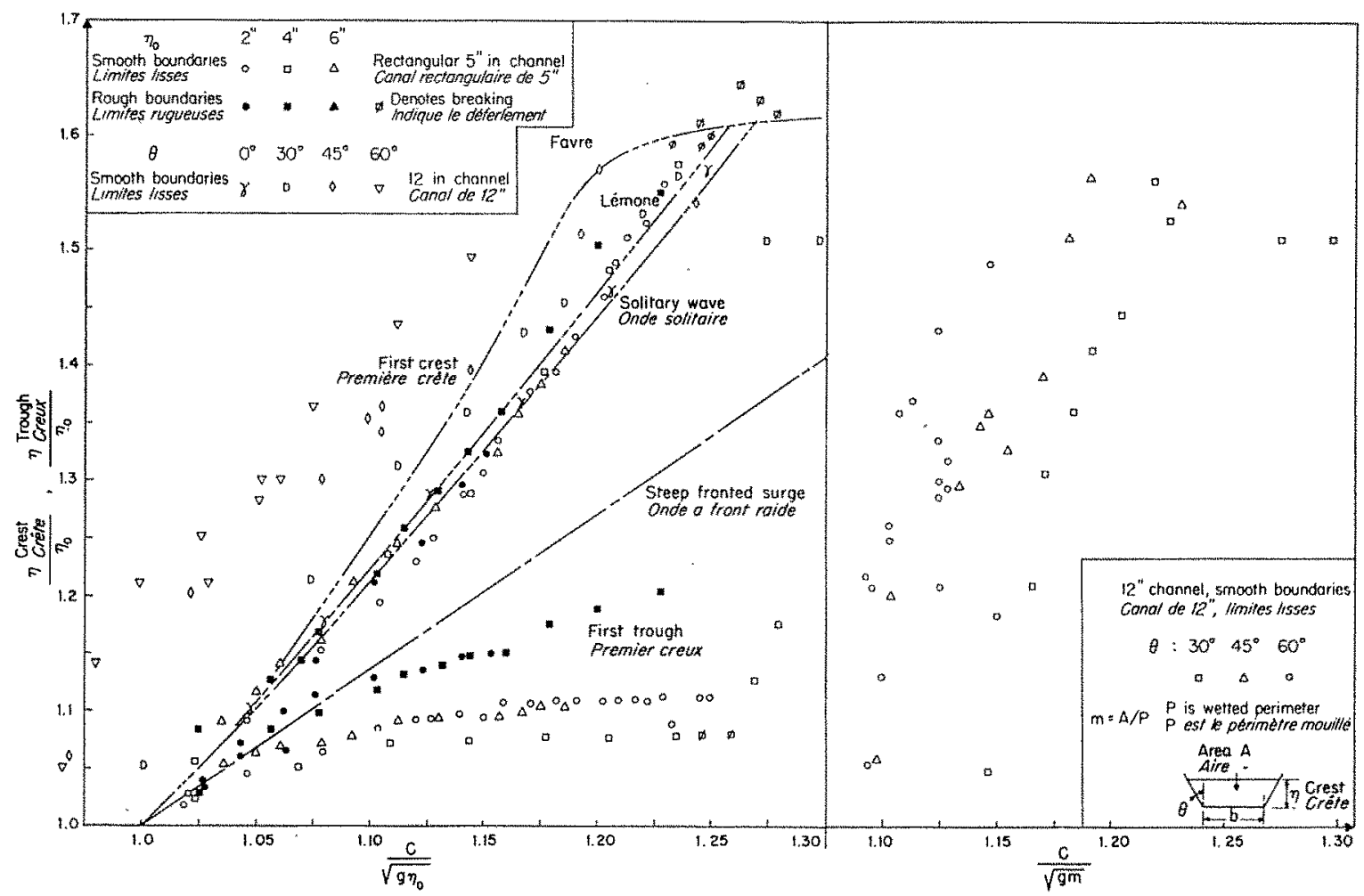

Fig. 10. 
waves break are much less pronounced when $0=45^{\circ}$, but the profiles after breaking are less regular. The changes are even less noticeable when $\theta=60^{\circ}$, because the conditions are such that the channel can almost be considered as a much wider rectangular channel.

When the original experiments were carried out in a rectangular channel, further results were obtained with the walls artifically roughened with wire netting. When the maximum depth was plotted against the discharge in nondimensional form the friction effects were clearly indicated, but these effects obscured any similarities between the wave heights. The results were therefore plotted again, Figure 10 , as

$$
\eta_{\text {crest }} / n_{0} \text { to } c / \sqrt{g n_{10}}
$$

where $c$ is the velocity of the surge wave and $\eta_{\text {crest }}$ is the height above the centre line of the channel. A correlation is apparent when $\theta=0^{\circ}$, since friction appears to have little effect on the first wave height. This is not altogether an unexpected result since it was demonstrated by Scott Russell [9] and Airey [1] that the wave height depends, in shallow water and in two dimensional flow, almost entirely on the depth of flow.
Scott Russell's empirical result

$$
c=\sqrt{g \eta_{\max }}
$$

was checked in the earlier experiments and the discrepancies between the observed and calculated values of $c$ were very small.

When, however, the results obtained in the prismoidal channel are inspected it is evident that there are marked differences and the values of $c / \sqrt{g n_{10}}$ for small values of initial discharge are less than unity. This is due to the fact that the mean depth in the channel is less than the maximum depth and therefore the mean velocity of the surge waves will be less than the velocity, in two dimensional flow, associated with the maximum depth. The results were therefore replotted in Figure 10 as

$$
\eta_{\text {crest }} / \eta_{0} \text { to } c / \sqrt{g m}
$$

where $m$ is the hydraulic mean radius relative to $\eta_{\text {crest* }}$

It is still evident, however, that a considerable difference exists, although the general form of the results are similar from one angle to another. Therefore, since as already stated, friction has little if any effect

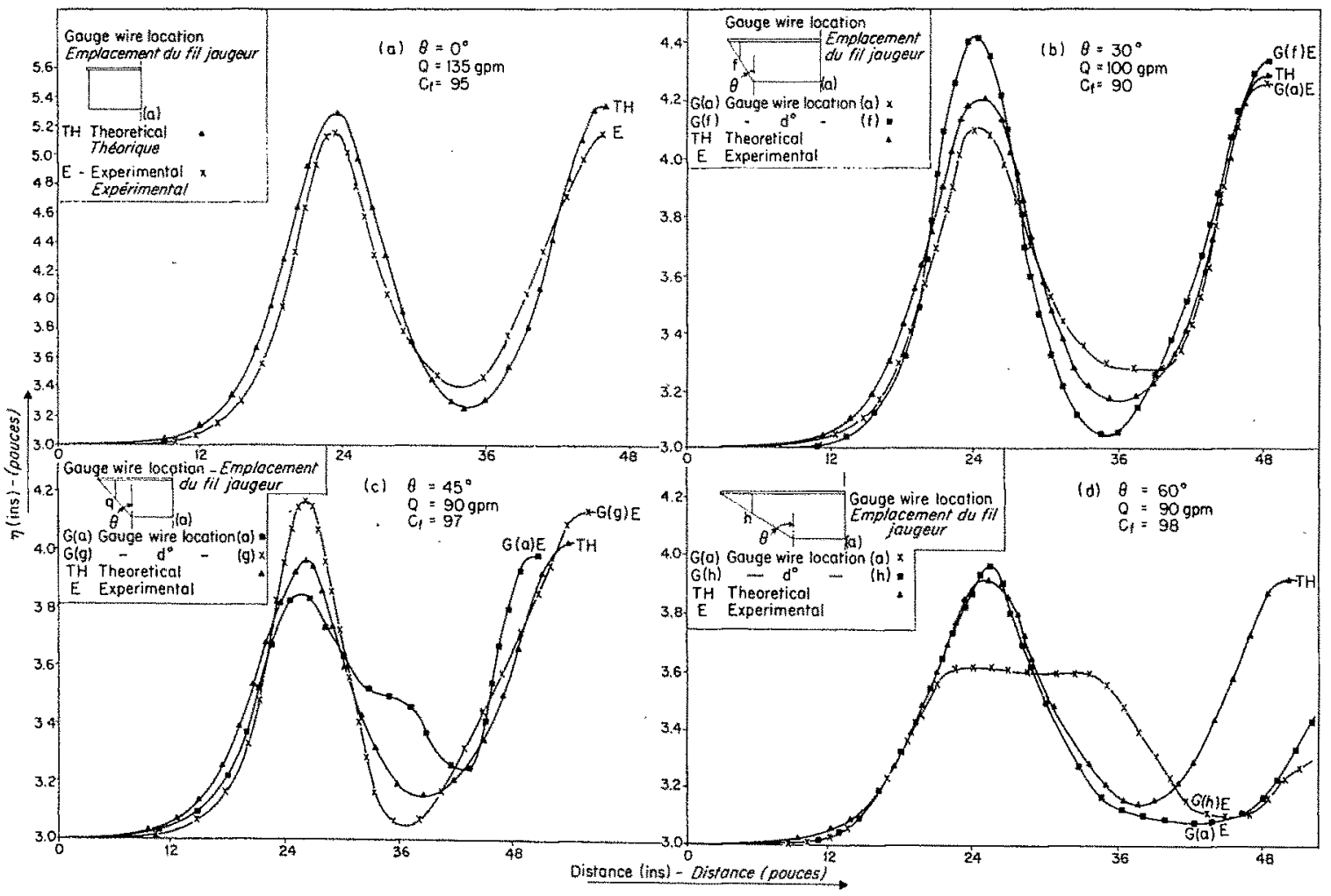

Fig. 11.

Comparison of experimental and theoretical determined surge wave profles in an open channel with varying side slopes (0). (Gauge position 4.) Confrontation des profils de front d'onde observés ct théoriques dans un canal découvert comportant des parois a inclinaison variable $(\theta)$. (Station de jaugeage $n^{\circ} 4$. ) 
on the first wave height, these variations must be due to channel shape.

It can also be seen from a consideration of Figure 10 that friction has a most marked efrect, in a rectangular channel, on the trough depth. It can further be shown in a similar manner, that friction noticeably afrects the wave lengths of the undulations.

\section{COMPARISON OF THEORETICAL AND EXPERIMENTAL RESULTS}

The comparison between these results is indicated in Figure 11. In the rectangular channel, the agreement is good. When $\theta=30^{\circ}$ and $45^{\circ}$, the theoretical first crest depth is slightly less than the crest depth at the wall, but is larger than the crest depth in the centre line of the channel. At these angles, however, much better correlation is observed when comparing the wave lengths and second crest depths.
When $\theta=60^{\circ}$, the theoretical result is almost equal to the maximum practical value at the first and second crest, but the wave lengths differ considerably.

It must he emphasised that the experimental conditions were chosen such that the discharge was less than that required to cause breaking of the side waves.

\section{CONCLUSIONS}

It is evident that the shape of undular surge waves depends upon channel friction and channel shape. In rectangular channels, the theoretical analyses due to Serre and other workers, appears to be vindicated but no previous analysis has been attempted for undular surge waves propagated in prismoidal channels.

Whilst this analysis is of a necessity approximate, the calculated profiles, although not being in complete agreement with the experimental results, are of value as they indicate the maximum crest height, if the side waves have not broken. The maximum error under the worst conditions is less than $10 \%$ and when the side waves have broken, the calculated maximum height will be greater than that occurring in practice. The most interesting feature in this investigation, was the large variations in crest height across the channel section and these would, in practice, necessitate maximum possible depths of flow considerably greater than the mean depth. Il must be noted, however, that the maximum wave height is invariably less when the surge is propagated in a channel of prismoidal section. This is due to the considerable Ioss in energy when the side wave breaks.

This work was undertaken in the Engineering Laboratories of the University College of Swansea and the authors are indebted to the Department of Scientific and Induslrial Research for a srant covering the cost of the equipment.

The writers also wish to express their thanks to Messrs. Standard Telephones and Cables Company Litd. for the use of their computer and for assistance in the programming of the computations.

\section{BIBLIOGRAPHY}

[1] Airey (Sir G. B.). - Tides and Waves. Encyclopaedia Metropolitania, London, pp. 241-396, 1845.

[2] Benjamin (T. B.) and LighthrLi (L.J.), - On Cnoidal Waves and Bores. Proceedings of the Royal Society; vol. 224, p. $448,1954$.

[3] Digital Computer. - Standard Telephones and Cables Ltd., Newport. The Standard Programme was devised and written at the University of Lausanne.

[4] Favre (H.). - Ondes de Translation. Dunod, Paris, 1935.

[5] IPPEN (A.T.). - Damping Characteristics of the Solitary Wave. Tech. Rep., 16. M.I.T., April 1955.

[6] Iwasa $(\dot{Y}$.$) . - Analytical Considerations on Cnoidal$ and Solitary Waves. Memoirs of the Faculty of Eng., Kyoto University, Japan, vol. XVII, No. IV, 1955.

[7] Lemorne (R.). - Sur les ondes positives de transm lation dans les canaux découverts. La Houlle Blanche, Nr. 2, March-April 1948, p. 183.

[8] Runae and KutTa. - Numerical Analysis, with emphasis on the application of numerical techniques to problems of Infinitesimal Calculus in a Single Variable, by Kopal (Z.). Chapman and Hall hid., p. 122,1955

[9] Russex. (I.S.). - Report on Waves. The Report of the British Assoc. for the Advancement of Science, p. 417,1837 ; p. 311,1844 .

[10] SANDoven (J.A.) and ZIExhewic: (O. C.). - Experiments on Surge Waves. Wrale Pomer, vol. 9 , p. 213, June 1957; vol. 9, p. 4[8, Nov. 1957.

[11] SANpoven (J.A.) and TAybon (C.). -.- Determination of the proflles of Water. Waves, Journal of Seienlific Instruments, vol. 37, pp. 141-143, 1960.

[.12] Senne (F.). - Contribulion à l'étude des ecoulements permanents et variables dans les canaux. La Honille Blanche, No. 3, pp. 374-388, June-July, 1953; No. 6, pp. 830-872, Decembre 1953 .

[13] Taylon (C.). - Undular Surge Waves in Prismoidal Channels. $7 /$. D. Thesis, University College, Swansea, 1960.

[14] Wieger (R. L.). - Cnoilal Wave Theory. Jonrnal of Fluid Mechanics, 7, 2, 273, Feb. 1960. 


\section{Les ondes de translation et les ondulations de front d'onde}

PAR

\author{
J.A. SANDOVER, \\ B.SC., PH.D., D.I.C., A.M.I.C.E., A.C.G.I.
}

ET

\author{
C. TAYLOR,
}

B.SC., PH.D.

(Voir les illustrations et la bibliographie dans le texte anglais, p. 443)

\begin{abstract}
Une étude par $F$. Serre sur des ondes de ce genre a paru dans deux numéros de La Houille Blanehe en 1953. Le traitement de ce problème a ensuite été repris par l'un des antenrs de la présente étude, qui l'a appliqué au cas des ondes provoquées, dans les canaux déconverts de section rectangulaire, par l'introduction soudaine d'un débit à P'ane des extrémités du canal. Les équations ont été résolues au moyen d'un calcul par différences finies, et les résultats obtenus ont été vériflés par une étude expérimentale de très grande envergure. Cette étude, évoquée entre autres dans le présent mémoire, est décrite dans la référence [10] de la bibliographie.

En 1958, les présents auteurs ont étendu les etudes theoripnes et experimentales au cas de la formation d'ondulation de front d'onde dans les canaux de section trapézoüdale; les essais
\end{abstract}

\begin{abstract}
correspondants furent effectuds dans un canal de 60 pieds $(18,3 \mathrm{~m})$ de long, et comportant des parois $\dot{a}$ inclinaison réglable, à volonté, par rapport a la verticale. Les résultats théoriques s'accordaient plus ou moins bien avec les résultats expérimentaux, mais moins bien que pour l'étude en canal rectangulaire. La principale différence constatée, dass le cas du conal trapézoüdal, clait que le profil latéral réel des crêtes d'onde presentait une forme courbe, alors que lo profll theorique etait rectiligne, ceci a canse des importantes simplificalions ndmises pour le developpement de la theorie. Le pressent mémoire traite de l'analyse théori$q u e$, et de la confrontation des résultats; ceuxci sont présentés sous forme adimensionnelle, afin d'en permettre l'extrapolation $\dot{a}$ des canaux de plus grandes dimensions.
\end{abstract}

\section{INTRODUCTION}

L'introduction brusque, à l'une des extrémités d'un canal découvert, d'un débit fluide relativement faible dans une masse d'eau au repos, provoque une onde comportant des ondulations de front d'onde, dont le profil longitudinal est représenté, pour un canal de section rectangulaire, par la figure $1 a$.

Le nombre des ondulations croît à mesure que cette perturbation se propage vers l'aval. En même temps, la hauteur de la crête de chaque ondulation successive augmente, pendant que l'onde parcourt une distance relativement courte; cette hauteur diminue ensuite unifor- mément sous l'influence du frottement. Lorsque le débit initial dépasse une certaine valeur limite (laquelle est fonction, à la fois, des dimensions, du profil, èt de la rugosité du canal, ainsi que de la profondeur d'eau au point d'introduction du débit), la première ondulation du front d'onde atteint une valeur maximale, et déferle (fig. $1 \mathrm{~b}$ ). L'agitation de l'eau, due au déferlement, disparâ̂t à mesure que l'onde se propage le long du canal, et, à condition que le débit initial soit d'une valeur suffisamment importante, la première ondulation croît de nouveau, jusqu'au nouveau déferlement. Ce phéno- 
mène se renouvelle tout le long du canal, jusqu'à ce que le débit effectif du front d'onde se trouve réduit, par frottement, à une valeur inférieure à la valeur limite. Dans ces conditions, la première ondulation du front d'onde ne déferle plus, mais, comme avant, les amplitudes augmentent rapidement, jusqu'à atteindre une valeur maximale, et décroissent ensuite uniformément. Lorsque le débit initial est encore plus grand, l'onde apparaît sous la forme d'une masse d'eau à front raide (fig. $1 \mathrm{c}$ ), ressemblant à un ressaut hydraulique en mouvement; elle se transformera en onde avec des ondulations de front d'onde déferlantes, et ensuite en une onde dont les ondulations ne déferlent plus, à mesure que le débit effectif du front d'onde diminue, sous l'influence du frottement. Ce phénomène a déjà été décrit par Favre [4], et par les présents auteurs [10], pour le cas des fronts d'onde dans les canaux rectangulaires. D'autres études expérimentales ont été effectuées depuis lors [13], ayant pour objet la détermination des profils de front d'onde dans les canaux prismatiques; l'analyse théorique précédente a également, moyennant certaines modifications, été étendue à ce problème. Les ondulations ne présentent plus, toutefois, les formes régulières de la figure $1 a$, sauf aux très faibles débits, car les ondes tendent à déferler, de la manière attendue, contre les parois du canal, où la profondeur est effectivement nulle. Notons en passant que ce phénomène est appelé «le déferlement des ondes latérales ». L'utillité de l'analyse théorique est done, dans ce cas, encore plus res- treinte que pour le cas des canaux rectangulaires, pour lesquels la concordance entre les résultats théoriques et pratiques était excellente, sauf pour l'amplitude d'onde voisine de la valeur limite de déferlement. Cette analyse portait sur une gamme de valeurs correspondant à un rapport \& profondeur maximale/profondeur non-perturbée » d'environ 1: 1,75, alors que, dans les canaux prismatiques, ce rapport était seulement de l'ordre de $1: 1,5$, pour une inclinaison des parois de $30^{\circ}$ par rapport à la verticale, et de 1 : 1,3 pour une inclinaison de $60^{\circ}$. Au contraire, la variation de l'amplitude d'onde était noins prononcée, lorsque les ondes latérales déferlaient, que lorsque l'onde entière déferlait, tant dans les canaux rectangulaires que dans les canaux prismatiques.

Une deuxième différence, d'ailleurs très intéressante, était la variation de la profondeur d'eau sous la crête de l'onde, en travers du canal prismatique, laquelle se voit nettement dans les figures 7 et 9 . Cette variation n'a malheureusement pas pu être prédite par la théorie, étant donné que, suivant l'une des hypothèses admises, les composantes latérales de la vitesse étaicnt considérées comme négligeables.

Enfin, nous avons pu constater la présence d'ondes secondaires «en queue de poisson》 lesquelles étaient, vraisemblablement, provoquées par des phénomènes liés à l'écoulement latéral; lorsque l'inclinaison des parois élait de $60^{\circ}$, les ondes secondaires masquaient les ondes primaires.

\section{ANALYSE THEORIQUE}

Il a été démontré par Serre [12], et, par ailleurs, par Benjamin et Lighthill [2], d'une part, que des ondulations de front d'onde stables sont théoriquement possibles, et, d'autre part, que la forme des ondulations, dans un écoulement plan, est décrite avec une bonne approximation par la courbe correspondant au carré de la fonction elliptique jacobienne en $x$. Les profils de ces formes d'onde ont été déterminés par voie expérimentale, et les résultats théoriques et expérimentaux ont été comparés [10]. Cette comparaison sera étendue; ci-après, aux résultats obtenus dans les canaux prismatiques. Afin de rendre les équations régissant ce mouvement indépendantes $\mathrm{du}$ temps, on impose au système une vitesse égale et opposée à la vitesse de propagation de la première onde. L'écoulement se trouve ainsi réduit à un écoulement en régime permanent; dans ces conditions, le front d'onde s'assimile à un ressaul hydraulique (fig. 1), mais dont les limites se déplacent.

L'équation de quantité de mouvement permet d'obtenir une relation en fonction de quantités connues, exprimant la pente du plan d'eau à une distance donnée de l'origine; cette expression permet de déterminer le profil d'onde, au moyen d'un procédé de différences finies. En considérant, dans la figure 1 , la surlace délimitée par les ordonnées $y$ en $B$ et en $C$, par le fond du canal, et par la surface libre, et en admettant que la répartition des vitesses à travers la section est uniforme, que le fond du canal est horizontal, que l'écoulement est incompressible, et que les phénomènes de frottement se déroulent seulement à l'intérieur de la couche limite, l'équation de la quantité de mouve- 
ment, dans la direction $x$. peut être exprimée sous la forme:

$$
\begin{gathered}
\iint_{\mathrm{B}} \frac{p}{\rho g} d \mathrm{~A}+\frac{\mathrm{QU}_{\mathrm{B}}}{g}-\iint_{\mathrm{c}} \frac{p}{\rho g} d \mathrm{~A}-\frac{\mathrm{QU}_{\mathrm{C}}}{g} \\
=\frac{\tau_{f}}{\rho g}(b+2 n \sec \theta) \delta x
\end{gathered}
$$

dans laquelle :

$$
\begin{aligned}
p= & \text { la pression locale; } \\
\mathrm{Q}= & \text { Le débit équivalent, en régime perma- } \\
& \text { nent; } \\
\mathrm{U}= & \text { La vilesse moyenne dans la section, en } \\
& \text { régime permanent; } \\
\eta= & \text { La hauteur d'eau dans la section; } \\
\theta= & \text { L'angle d'inclinaison des parois du } \\
& \text { canal, par rapport à la verticale; } \\
\tau_{0}= & \text { La contrainte de cisaillement, à la } \\
& \text { Limite. }
\end{aligned}
$$

Les indices $\mathrm{B}$ et $\mathrm{C}$ correspondent aux sections considérées.

En admettant des hypothèses simplificatrices complémentaires, il est possible de résoudre cette expression, et de déterminer le profil de la surface libre. On déterminera d'abord la fonction de la quantité de mouvement :

$$
\mathrm{M}=\iint \frac{p}{\rho g} d \mathrm{~A}+\frac{\mathrm{QU}}{g}
$$

Le fait que les éléments fluides peuvent présenter une courbure appréciable, rend inadmissible l'hypothèse d'une répartition hydrostatique des pressions; cette répartition doit donc ètre déterminée à partir de l'équation dynamique d'Euler :

$$
\frac{1}{\rho g} \frac{\partial p}{\partial y}=-1-\frac{p}{g} \frac{\partial v}{\partial y}-\frac{u}{g} \frac{\partial v}{\partial x}-\frac{w}{g} \frac{\partial v}{\partial z}
$$

dans laquelle $u, l$ et $w$ sont, respectivement, les composantes de vitesse dans les directions $x, y$ et $z$.

Deux simplifications arbitraires doivent être faites à ce moment : d'une part, la supposition que la composante de vitesse latérale est négligeable devant les composantes $x$ et $y$, et d'autre part, que la répartition des vitesses est supposée être uniforme, c'est-à-dire que $u=\mathrm{U}$ (la vitesse moyenne de l'écoulement dans la direction $x$ ). Aux faibles valeurs de la pente latérale $\theta$, il est, évidemment, possible de justifier la première de ces deux suppositions, mais pour que l'hypothèse d'une répartition uniforme des vitesses le soit également, même de manière approximative, l'écoulement devra être turbulent, et la pente latérale, ainsi que l'amplitude de l'onde, devront être faibles. Nous avons, par conséquent, d'abord essayé d'aborder le problème sans avoir recours à ces simplifications, mais les équations obtenues étaient extrêmement complexes, au point de paraître pratiquement irrésolvables, ̀̀ moins d'admethe une série d'hypothèses très poussées. Nous arons donc jugé préférable d'admettre les deux hypothèses mentionnées plus haut, dès ce stade préliminaire de l'analyse du problème. Liexamen de la figure 11 montre, cependant, que ces deux hypothèses ne sont pratiquement plus justifiées. lorsque l'inclinaison de la paroi du canal dépasse $45^{\circ}$ par rapport à la verticale. Mais puisque, pratiquement, il est peu probable que l'inclinaison des parois dépasse cette valeur, les résultats théoriques présentent néanmoins une certaine utilité dans les cas où les ondes latérales ne déferlent pas. Par contre, dès qu'il y a déferlement, la solution théorique devient infiniment plus complexe, et il est nécessaire d'avoir recours à des résultats expérimentaux.

Afin de pouvoir passer à l'intégration de l'équation (3), il faut déterminer $v, u, \partial v / \partial y$ et $\partial v / \partial x$. Puisque, d'après la figure 2 :

$$
u=\mathrm{U}=\frac{\mathrm{Q}}{\eta(b+\eta \operatorname{tg} 0)}
$$

$\eta$ étant la hauteur d'eau locale, il s'ensuit que :

$$
\frac{d u}{d x}=-\frac{\mathrm{Q}(b+2 \eta \operatorname{tg} 0)}{\eta^{2}(b+\eta \operatorname{tg} \theta)^{2}} \frac{d \eta}{d x}
$$

Par ailleurs, puisque l'équation de continuité se présente sous la forme:

$$
\frac{\partial u}{\partial x}+\frac{\partial v}{\partial y}=0
$$

et, en admettant que $u$ est uniquement fonction de $x$ (hypothèse très restrictive, et à l'origine de la plupart des écarts entre les résultats théoriques et pratiques), nous avons :

$$
\frac{\partial u}{\partial x}=\frac{d u}{d x}
$$

d'où :

$$
\frac{\partial v}{\partial y}=+\frac{Q(b+2 \eta \operatorname{tg} \theta)}{\eta^{2}(b+\eta \operatorname{tg} \theta)^{2}} \cdot \frac{d \eta}{d x}
$$

L'intégration de cette expression, par rapport à $y$, nous donne:

$$
v=+\frac{\mathrm{Q}(b+2 \eta \operatorname{tg} \theta)}{\eta^{2}(b+\eta \operatorname{tg} \theta)^{2}} \frac{d \eta}{d x} y
$$

puisque, pour $y=0, v=0$, et qu'ainsi la constante d'intégration est nulle. En tirant les déri- 
vées de cette équation, par rapport à $x$, nous obtenons :

$$
\begin{aligned}
\frac{\partial v}{\partial x} & =\frac{\mathrm{Q}(b+2 \eta \operatorname{tg} \theta)}{\eta^{2}(b+\eta \operatorname{tg} \theta)^{2}} y \frac{d^{2} \eta}{d x^{2}} \\
& -2 \mathrm{Q}\left[\frac{b^{2}+3 b \eta \operatorname{tg} \theta+3 \eta^{2} \operatorname{tg}^{2} \theta}{\eta^{3}(b+\eta \operatorname{tg} \theta)^{3}}\right] y\left(\frac{d \eta}{d x}\right)^{2}
\end{aligned}
$$

Le gradient de pression, dans la direction $y$ (équation 3) peut, dès lors, être exprimé en fonction de $Q, \eta, b, x$ et $\theta$, et l'intégration de cette expression, par rapport à $y$, nous donne :

$$
\begin{array}{r}
\frac{p}{\rho g}=(\eta-y)-\left[\frac{\mathrm{Q}^{2}\left(\eta^{2}-y^{2}\right)}{2 g \eta^{3}(b+\eta \operatorname{tg} \theta)^{3}}\right] \\
{\left[\left(\frac{b^{2}+2 b \eta \operatorname{tg} \theta+2 \eta^{2} \operatorname{tg}^{2} \theta}{\eta(b+\eta \operatorname{tg} \theta)}\right)\left(\frac{d \eta}{d x}\right)^{2}\right.} \\
\left.-(b+2 \eta \operatorname{tg} \theta) \frac{d^{2} \eta}{d x^{2}}\right]
\end{array}
$$

La superficie de l'élément hachuré de la figure 2 est :

$$
\delta \mathrm{A}=b \delta y+2 y \operatorname{tg} \theta \delta y
$$

Et puisque $x$ et $\eta$ sont des constantes, nous pouvons exprimer l'équation (4) sous la forme :

$$
\frac{p}{p g}=f(y)
$$

L'équation (2) peut donc être mise sous la forme :

$$
\mathbf{M}=\int_{0}^{\eta} f(y)(b+2 y \operatorname{tg} \theta) d y+\frac{Q^{2}}{g \eta(b+\eta \operatorname{tg} \theta)}
$$

et, en intégrant l'équation (4), par rapport à $y$, nous pouvons écrire l'équation (5) de la manière suivante :

$$
\frac{d^{2} \eta}{d x^{2}}-\varphi_{1}(\eta)\left(\frac{d \eta}{d x}\right)^{2}-\varphi_{2}(\eta)=0
$$

avec :

$$
\phi_{1}(\eta)=\frac{1}{\eta}\left[\frac{b^{2}+2 \eta b \operatorname{tg} \theta+2 \eta^{2} \operatorname{tg}^{2} \theta}{(b+\eta \operatorname{tg} \theta)(b+2 \eta \operatorname{tg} \theta)}\right]
$$

et :

$$
\begin{aligned}
& \varphi_{2}(\eta)=\left[\frac{12 g(b+\eta \operatorname{tg} \theta)^{3}}{Q^{2}(3 \eta \operatorname{tg} \theta+4 b)(b+2 \eta \operatorname{tg} \theta)}\right] \\
& {\left[M_{x}-\frac{\eta^{2}}{6}(3 b+2 \eta \operatorname{tg} 0)-\frac{Q^{2}}{g \eta(b+\eta \operatorname{tg} \theta)}\right]}
\end{aligned}
$$

(laquelle est la forme différentielle de l'équation (2)).

La résolution de l'équation (6), en admettant que $\mathbf{M}_{x}$ soit une constante, permet de démontrer que la solution obtenue représente le profil d'une onde solitaire. D'après ce résultat, la contrainte de cisaillemenl de l'équation (1) serait, à la limite, nulle; dans ces conditions, la forme de cette onde resterait la même pendant son déplacement sur toute la longueur du canal. Mais ceci ne signifie guère qu'une forme d'onde solitaire quelconque ne puisse exister dans un canal réel, présentant des phénomènes de frottement. Ce phénomène a été éludié par plusieurs auteurs, avec beaucoup de succès [5]. Benjamin et Lighthill [2] montrent qu'une onde stationnaire solitaire est la seule perturbation pouvant paraître dans un canal découvert à partir d'un écoulement permanent uniforme, sans entraîner de variations de quantité de mouvement, ou d'énergie, et que, lorsque de telles variations se produisent, la perturbation présente un profil d'ondulation. Cette dernière remarque de Benjamin el Lighthill ne contredit d'ailleurs guère celle faite précédemment, à savoir qu'une onde solitaire peut exister dans un canal réel, car une telle onde solitaire correspond, en réalité à la première ondulation d'un front d'onde. Ces auteurs montrent également que la théorie linéarisée de Lemoine [7] n'est guère valable pour des ondulations de front d'onde, puisque les longueurs d'onde et les amplitudes des ondulations individuelles sont trop importantes. En fait, pour le profil considéré comme sinusoildal par Lemoine, la seule onde possible est une onde solitaire.

11 importe donc, évidemment, d'étudier l'influence de la rugosité des parois.

\section{Frottement aux limites}

L'équation (1) peut également être écrite sous la forme :

$$
M_{x t}-M_{(x)+\delta x)}=-\frac{\tau_{g}}{\rho g}(b+2 \eta \operatorname{secc} 0) \delta x
$$

ou bien:

$$
\frac{d \mathrm{M}}{d x}=+\frac{\tau_{0}}{\varphi g}\left(b+2 r_{1} \operatorname{sic} 0\right)
$$

Si l'on admet un coefficient de froltement superficiel :

$$
c_{f}=2 \tau_{0} / \mathrm{U}_{m}^{2}
$$

avec le coefficient de rugosité de Chézy :

$$
\mathrm{C}=\left(2 g / c_{f}\right)^{1 / 2}
$$

et, comme cela est évident d'après la figure 1,

$$
\mathrm{U}_{m}=-\left(\mathrm{U}_{a}\right)=\mathrm{U}_{0}-\mathrm{U}_{1} \text {, }
$$


on a :

$$
\begin{array}{r}
\frac{d \mathrm{M}}{d x}=\frac{Q^{2}(b+2 \eta \sec 0)}{\mathrm{C}^{2}}\left[\frac{1}{\eta_{0}\left(b+\eta_{\theta} \operatorname{tg} \theta\right)}\right. \\
\left.-\frac{1}{\eta(b+\eta \operatorname{tg} \theta)}\right]^{2}
\end{array}
$$

dans laquelle l'indice 0 correspond à un régime sans perturbation. Dans ces conditions, l'équation (6) pourrait prendre la forme :

$$
\frac{d^{2} \eta}{d x^{2}}-p_{1}(\eta)\left(\frac{d \eta^{2}}{d x}\right)-\varphi_{3}\left(\eta, M_{x}\right)=0
$$

La solution de cette équation, en fonction de $r_{\text {i }}$ et de $x$, représenterait le profil longitudinal d'un front d'onde du type «mascaret» dans un canal prismatique ouvert. Cette analyse n'est toutefois valable, que si, d'une part, les ondulations $d u$ front d'onde n'ont pas déferle, et si, d'autre part, C peut être déterminé.

Nous avons établi l'expression suivante, pour la pente de la ligne d'eau dans un canal prismatique, et pour un écoulement variant progressivement :

$\frac{d \eta}{d x}=\left[\frac{Q_{f}^{2}(b+2 \eta \operatorname{séc} \theta)}{\mathrm{C}^{2} \eta^{3}(b+\eta \operatorname{tg} \theta)^{3}}\right]\left[\frac{1}{1-\frac{\mathrm{Q}^{2}}{g \eta^{3}} \frac{(b+2 \eta \operatorname{tg} \theta)}{\left(b+\eta_{1} \theta\right)^{3}}}\right]$

$Q_{f}$ étant le débit.

Plusieurs régimes d'écoulement variant progressivement ont été reproduits successivement, et la valeur de $\mathrm{C}$ a été obtenue à l'endroit où ont été enregistrées les ondes dans le canal, compte tenu de différentes hauteurs d'eau $\eta$ (définies par un volet déversant à l'extrémité aval du canal), et de différents débits $Q_{f}$. Les valeurs de $C$ ainsi obtenues ont ensuite été portées en fonction d'une valeur $r$ équivalente du nombre de Reynolds :

$$
r={ }^{\prime} \mathcal{R}_{\mathrm{N}}=\mathrm{U} m=\frac{\mathrm{Q}_{t}}{(b+2 \eta \operatorname{séc} \theta)}
$$

Dans cette expression, $m$ est le rayon hydraulique moyen de l'écoulement, et v est la viscosité cinématique du liquide. Il a été admis, ensuite, que si $r$ pouvait également être déterminé pour différentes hauteurs d'écoulement dans le corps de l'onde, on pourrait alors obtenir directement la valeur de $\mathrm{C}$ correspondante d'après les courbes $\mathrm{C}=f(r)$, c'est-à-dire que la similitude dynamique serait établie. Afin, toutefois, de rendre cette opération possible, il est nécessaire d'établir la relation entre $Q, Q_{a}$ et $\mathrm{Q}_{f}, \mathrm{Q}_{a}$ étant le débit réel déclenchant l'onde.

$Q$ se détermine à partir de la relation :

$$
\mathrm{Q}=c \mathrm{~A}_{0}=\mathrm{U}_{0} \mathrm{~A}_{0}
$$

dans laquelle $c$ est la vitesse de l'onde, laquelle peut être déterminée par voie expérimentale, et :

d'où :

$$
\begin{gathered}
\mathrm{U}_{a}=-\left(\mathrm{U}_{0}-\mathrm{U}_{1}\right) \\
\mathrm{Q}_{a}=-\left(\mathrm{U}_{0}-\mathrm{U}_{1}\right) \mathrm{A}_{1} \\
=\mathrm{Q}\left[\frac{\eta(b+\eta \operatorname{tg} \theta)}{\eta_{0}\left(b+\eta_{0} \operatorname{tg} \theta\right)}-1\right]
\end{gathered}
$$

Or dans la section 1 (fig. 1), $r$ est exprimé, sous l'onde, par :

$$
r=\mathrm{U}_{\mathrm{o}} m=\frac{\mathrm{Q}_{n}}{\mathrm{~A}}=\frac{\mathrm{Q}_{a}}{b+2 n \operatorname{séc} \theta}
$$

Il s'ensuit que $Q_{b}$ doit être égal à $Q_{f}$, pour qu'il $y$ ait similitude dynamique. Dans ces conditions, on peut déterminer $Q$, pour n'importe quelle vitesse $c$ de l'onde, et $Q_{a}$ et $r$ pour toute hauteur d'eau $\eta$. Ceci permet de déterminer $C$, en fonction de la valeur appropriée de $Q_{f}$, égale à $\mathrm{Q}_{a}$. ̀̀ partir de la courbe $\mathrm{C}=f(r)$.

Afin de faciliter les calculs, nous avons tracé deux familles de courbes complémentaires (fig. $3 b$ et $3 c$ ), l'une pour $\eta=f(r)$, et l'autre pour $\eta_{1}=f\left(Q_{a}\right)$, respectivement, d'après les relations exprimées par les équations (15) et (16). Connaissant $Q$ et $\eta$, on peut déterminer $Q_{a}$ à partir de la figure $3 c$, et $r$ à partir de la figure $3 b$. Dans ces conditions, $Q_{a}$ est égal à $Q_{f}$, ce qui permet de déterminer $\mathrm{C}$ à partir de la figure $3 a$.

La méthode que nous avons employée pour déterminer $\mathrm{C}$ expose, nous le savons, à des critiques, surtout puisque l'écoulement en tête de londe doit être laminaire; on doit espérer que des études complémentaires permettront, par la suite, de voir si ce problème peut être abordé à l'aide de la théorie des couches limites.

La présente méthode ne pourrait convenir à un emploi pratique, car elle impliquerait la connaissance des données avant que le canal ne soit réalisé; on a pu constater, toutefois, que plus le canal est grand, plus la valeur de C s'approche de la valeur empirique fournie par une expression telle que la formule de Manning. Il semblerait donc qu'une valeur moyenne de $C$, obtenue par cette méthode, puisse être employće pour un canal de grandeur nature. La méthode employée pour déterminer le frottement superciel est justifiée par les très bons résultats qu'elle a fournis lors du calcul des profils de front d'onde dans les canaux de section rectangulaire.

\section{Résolution de l'équation 12}

L'équation équivalente (21) pour les canaux rectangulaires peut être résolue par une méthode de différences finies extrêmement laborieuse, en 
employant une machine à calculer de bureau [10], mais la résolution de l'équation (12), au moyen de ce même procédé, entraìnerait des dépenses injustifiahles de temps et de maind'œuvre.

Nous avons donc employé une calculatrice numérique, en appliquant la méthode d'analyse numérique par différences finies des équations différentielles du premier ordre de Runge Kutta $[3,8]$. L'équation à résoudre :

$$
\frac{d^{2} \eta}{d x^{2}}=\eta_{1}(\eta)\left(\frac{d \eta}{d x}\right)^{2}+\varphi_{3}(\eta, M)
$$

peut être réduite à trois équations différentielles simultanées du premier degré :

$$
\begin{gathered}
\frac{d \eta_{1}}{d x}=\zeta=\mathrm{F}_{1}(\zeta, \eta, \mathrm{M}) \\
\frac{d \zeta}{d x}=\varphi_{1}(\eta) \zeta^{2}+\varphi_{3}(\eta, \mathrm{M})=\mathrm{F}_{2}(\zeta, \eta, \mathrm{M})
\end{gathered}
$$

et, à partir de l'équation (11) :

$$
\frac{d \mathrm{M}}{d x}=\varphi_{4}(\eta, \mathrm{C})=\mathrm{F}_{3}(\zeta, \eta, \mathrm{M})
$$

$\varphi_{1}, \varphi_{3}$ et $\varphi_{4}$ étant des fonctions connues.

En connaissant les valeurs initiales de $\eta$, $\zeta$, et de M, et ayant porté les courbes de ces variables en ordonnées sur trois plans, en fonction de l'abscisse $x$, on obtient les pentes de ces courbes à partir de ces trois équations. Ces pentes, avec une valeur de $x=x_{0}+\delta x$, permettent alors de déterminer les nouvelles valeurs des pentes, et ainsi de suite, en reprenant toujours le même procédé, en calculant $\eta$ à partir des valeurs connues de $\delta x$ et de $d \eta / d x$. C'est ainsi que l'on obtient le profil de l'onde.

Ce profil est un profil d'ondulation, et peut être représenté, approximativement, par la courbe de fonction jacobienne elliptique $c n$. Cette théorie ne tient pas compte de l'influence du déferlement des ondes, de sorte que l'amplitude des ondes paraît continuer à croître sans limite. Mais, en réalité, lorsque le débit dépasse une certaine valeur limite, la première ondulation déferle avec une perte d'énergie due à la turbulence, et, ainsi que l'ont démontré Benjamin et Lighthill, l'amplitude décroît à mesure que cette perte d'énergie augmente. Il s'ensuit que la célérité de la première onde diminue, et, puisque la vitesse de la deuxième onde ne subit aucune réduction, le premier creux tend à se remplir d'eau. Ainsi, aux débits élevés, les creux sont complètement remplis, et l'onde comporte un front raide, au profil quasi rectiligne.

Le fait que $d \eta / d x=\zeta=0$ lorsque $x=0$, a donné lieu à une difficulté d'ordre pratique dans les calculs. On peut démontrer, dans la théorie de l'onde solitaire, que si $\eta_{0}$ subit une augmentation $\Delta r_{i}, x$ varie de 0 à l'infini. Nous avons donc établi, en procédant par tâtonnements, que $\zeta$ devrait être égal à 0,001 radian, pour la première valeur de $\Delta \eta_{i}$. L'incrément horizontal était égal à 0,05 pouce $(1,27 \mathrm{~mm})$, cette valeur ayant également été déterminée comme valeur oplimale au moyen d'un procédé par tâtonnements. La calculatrice employée ne permettait malheureusement pas d'employer une valeur variable de $\mathrm{C}$, et nous avons donc dû nous contenter d'une valeur moyenne. Ceci nous a obligé à exécuter un calcul d'essai pour $C$, avec des incréments de $\Delta \eta=0,1$ pouce $(2,54 \mathrm{~mm})$, et en admettant une valeur maximale pour $\eta$. Nous avons d'abord déterminé la moyenne arithmétique de C, et ensuite, calculé le profil du front d'onde. Dans les cas où la valeur de $\eta_{\text {max }}$ ainsi obtenue était différente de la valeur estimative, nous avons renouvelé le procédé, jusqu'à ce qu'il soit possible d'admettre une valeur à peu près prícise pour $\eta_{\max }$.

En bref, les détails pratiques de la résolution de l'équation (12) sont les suivants :

$$
\frac{d \zeta}{d x}=\varphi_{1}(\eta) \zeta^{2}+\varphi_{2}(\eta)
$$

$\eta_{0}$ étant connu, Q peut être déterminé par voie expérimentale, ou bien, pratiquement, au moyen de la méthode de Favre [4]; on admet, pour $\zeta_{0}$, une valeur de 0,01 radian. Les fonctions $\varphi_{1}$ et o. peuvent être déterminées à partir des équations (7) et (8), si l'on connait $\mathbf{M}_{\sigma}$, ainsi que la valeur initiale de la fonction de quantité de mouvement :

$$
\mathrm{M}_{x=0}=\frac{\eta_{10}^{2}}{6}\left(2 \eta_{0} \operatorname{tg} 0+3 b\right)+\frac{Q^{2}}{g \eta_{0}\left(b+\eta_{0} \lg 0\right)}
$$

Enfin, on choisit, pour «l'incrément» de calcul, $x=0,05$ pouce $(1,27 \mathrm{~mm})$. Il s'ensuit que :

a) $\zeta=0,001=d \eta / d x$ et puisque $\Delta x=0.05$, on peut déterminer une nouvelle valeur pour $r_{i}$, soit $\eta_{1}$;

b) La résolution de l'équation (11) s'effectue en employant $\eta_{1}$ pour obtenir une valeur de $d \mathrm{M} / d x$. De nouveau, la connaissance de $\Delta x$ permet de calculer la variation de la quantilé de mouvement $\Delta M$, de sorte que :

$$
\mathrm{M}_{0}+\Delta \mathrm{M}=\mathrm{M}_{1}
$$

c) En faisant intervenir la valeur de $\mathrm{M}_{1}=\mathrm{M}_{i,}$, on résout l'équation (17 b) pour obtenir $\zeta$;

d) On renouvelle les étapes $(a)$ à $(c)$, en portant en abaque les valeurs correspondantes de $\eta$ et de $x$. 


\section{Les ondulations de front d'onde dans les canaux rectangulaires}

On peut démontrer qu'il est possible d'obtenir une expression semblable à l'équation (12), pour un écoulement en canal prismatique, au moyen de l'équation de l'énergie, mais en faisant intervenir des valeurs différentes de $o_{1}, \varphi_{3}$, et de $o_{4}$. L'exécution d'une analyse semblable, pour le cas d'un canal de section rectangulaire [10] (c'est-à-dire en rendant égale à zéro la valeur de $\theta$ dans les équations précédentes), permet d'obtenir deux expressions similaires, mais simplifiées, pour la quantité de mouvement $M$, et pour l'énergie H. La combinaison de ces deux expressions fournit la relation :

$$
\frac{\mathrm{Q}^{2}}{6 g b^{2}}\left(\frac{d \eta}{d x}\right)^{2}=\mathrm{H} \eta^{2}-\frac{\eta^{3}}{2}+\frac{\mathrm{Q}^{2}}{2 g b^{2}}-\mathrm{M} \eta
$$

Les variations de la quantité de mouvement et de l'énergie se déterminent alors à partir des deux expressions suivantes :

$$
\begin{aligned}
& \frac{d \mathrm{M}}{d x}=\frac{\mathrm{Q}^{2}}{\mathrm{C}^{2} b^{3}}\left(\frac{1}{\eta_{0}}-\frac{1}{\eta}\right)^{2}(b+2 \eta) \\
& \frac{d \mathrm{H}}{d x}=\frac{\mathrm{Q}^{2}}{\mathrm{C}^{2} b^{2} \eta}\left(\frac{1}{\eta_{0}}-\frac{1}{\eta}\right)^{2}(b+2 \eta)
\end{aligned}
$$

Pour ce calcul, il a été employé des incréments de la hauteur d'eau $(\Delta \eta)$, et non des incréments $d x$. En prenant, au départ, les valeurs initiales de $\mathrm{H}$ et de $\mathrm{M}$, mais en admettant :

$$
\eta_{0}+\Delta \eta
$$

pour la hauteur d'eau, on peut obtenir une valeur de $d \eta / d x$, ainsi que la valeur de $\Delta x$. Les incréments de variation de $H$ et de $M$ peuvent être calculés, et employés avec la valeur de $\eta_{0}+2 \Delta \eta$, alin d'obtenir des nouvelles valeurs de $d \eta / d x$, etc.
Etant donné le manque de maniabilité de ces expressions, nous les avons remplacées par les formes adimensionnelles équivalentes, de sorte que, pour l'équation (8), nous avions :

$$
\frac{1}{6}\left(\frac{d \mathrm{Y}}{d \mathrm{X}}\right)^{2}=\mathrm{H}^{\star} \mathrm{Y}^{2}-\frac{\mathrm{Y}^{3}}{2}+\frac{1}{2}-\mathrm{M}^{\star} \mathrm{Y}
$$

dans laquelle :

$$
\begin{aligned}
\mathrm{Y} & =\eta / \eta_{\text {critique }} ; \\
\mathrm{H}^{\star} & =\mathrm{H} / \eta_{\text {eritique }} \\
\mathrm{M}^{*} & =\mathrm{M} / \boldsymbol{\eta}^{2} \text { critiqne }
\end{aligned}
$$

Afin de faciliter les calculs, ces expressions ont été modifiées encore une fois, ce qui a donné, pour l'équation (21):

$$
\begin{aligned}
& \frac{1}{6}\left(\frac{d \mathrm{Y}}{d \mathrm{X}}\right)_{n}^{2}=\frac{(n+1)^{2}(\Delta \mathrm{Y})^{2}\left(1-\mathrm{Y}_{0}\right)^{3}}{2 \mathrm{Y}_{0}{ }^{2}} \\
& -\frac{(n+1)^{3}(\Delta \mathrm{Y})^{3}}{2}+\Sigma \Delta \mathrm{H}^{\star} \cdot \mathrm{Y}_{n}{ }^{2}-\Sigma \Delta \mathrm{M}^{\star} \mathbf{Y}_{n}
\end{aligned}
$$

dans laquelle $n$ représente l'étape de calcul (numéro d'ordre du procédé), $\Sigma \Delta \mathbf{H}^{\star}$ la somme des termes exprimant l'énergie, et $\Sigma \Delta M^{\star}$ la somme des termes exprimant la quantité de mouvement.

Ces profils théoriques étaient, à peu de choses près, identiques aux profils obtenus par voie expérimentale, puisque les hypothèses admises différaient moins des conditions réelles que celles employées en déduisant des éçuations correspondantes pour les canaux prismatiques. Quant à ces dernières, il n'a pas été possible de combiner les équations de l'énergie et de la quantité de mouvement, en une seulc expression élégante telle que l'équation (18). On est, au contraire, obligé de résoudre une différentielle du deuxième ordre, ce qui complique les calculs encore davantage.

\section{ETUDES EXPERIMENTALES}

II a été construit un canal d'étude de 60 pieds $(18,3 \mathrm{~m}$ ) de long (fig. 4), dont le fond, en verre, était scellé dans du mastic, et reposait sur un profilé en « $U$ » en acier doux; les parois latérales du canal, en «perspex», étaient rattachées à des cornières en aluminium, ces dernières étant reliées par des charnières au profilé en acier supportant le fond du canal. Les dimensions de la section rectangulaire du canal ćtaient de $12 \times 12$ " $(30,5 \times 30,5 \mathrm{~cm}) ;$ un joint de caoutchoue, prévu derrière les charnières des parois, assurait l'étanchéité du canal, quelle que soit l'inclinaison des parois par rapport à la verticale. La hauteur des supports du canal audessus du sol était réglable, grâce à des vérins à vis prévus à cette fin, ce qui permettait de donner au canal n'importe quelle inclinaison longitudinale, jusqu'à la pente maximale de 0,01 . Nous avons cependant réalisé tous nos essais avec le canal en position horizontale.

La nécessité d'éviter la formation d'ondes secondaires a imposé un choix très soigneux des 
profils à l'entrée du canal. Nous avons prévu un élément de section rectangulaire, lecuel entourait les tuyaux d'alimentation, et constituait un «canal intérieur» se raccordant au canal d'étude proprement dit par l'intermériaire d'un divergent progressif.

Ce canal secondaire faisait partie d'un circuit d'écoulement, étant alimenté à partir d'une cuve à niveau constant. Les fronts d'onde ont été engendrés par l'introduction brusque d'un débit, commandée par un robinet-vanne, dans une masse d'eau au repos. La mesure de ce débit s'effectuait au moyen d'un manomètre à mercure, mais il pouvait être réglè auparavant, à une valeur approximative, au moyen d'un robinet à vis situé à l'amont du robinet-vanne.

Des expériences avaient dẻjà été réalisées antérieurement dans un canal de section rectangulaire, de 48 pieds $(14,63 \mathrm{~m})$ de long, de 10 pouces $(25,4 \mathrm{~cm})$ de large et de 5 pouces $(12,7 \mathrm{~cm})$ de haut $[10]$.

Elles avaient eu pour objet la détermination du profil et de la vitesse de propagation des ondulations de l'onde. Etant donné que, dans un canal rectangulaire, le mouvement est essentiellement à deux dimensions, il suffisait de déterminer les profils longitudinaux; cette détermination a été faite, soit par des procédés photographiques (fig, 5) soit au moyen de capacitances de mesure de profondeur, disposées suivant l'axe du canal (fig. 6). Malgré la complexité relative des circuits électriques nécessaires au fonctionnement des capacitances, elles ont néanmoins fourni des résultats plus sùrs que cenx obtenus par voie photographique; ces derniers ont, par conséquent, uniquement servi à vérifier les résultats fournis par les capacitances de mesure.

Dans les canaux prismatiques, au contraire, les formes des fronts d'onde sont moins régulières, puisqu'il s'agit là d'un écoulement à trois dimensions. La figure 7 montre un front d'onde représentatif, et met en évidence la formation. d'ondes secondaires en «queue de poisson» sur les ondulations principales, se coupant et se recoupant sur toute la largeur du canal. Des photographies de ces ondes, à elles seules, n'auraient présenté qu'une utilité très limitée, à moins d'avoir recours à une méthode photogrammétrique, telle que celle de Favre, par excmple. De même, puisqu'une seule capacitance, disposée sur l'axe du canal, n'aurait indiqué le profil que sur une seule section verticale, nous avons disposé plusieurs jauges, espacées uniformément, à traver's une moitié de la sec- tion, ceci à deux endroits diférents le long du canal [11]. Les valeurs mesurées au moyen de ces jauges ont permis de reconstituer une image à trois dimensions de l'onde et des rariations de la forme de celle-ci, et cela pour différentes valeurs du débit. Les mesures ont été effectuées pour différents débits, et pour des inclinaisons des parois du canal de $30^{\circ}, 45^{\circ}$, et de $60^{\circ}$, par rapport à la verticale. Un étalonnage statique a élé effectué avant chaque série d'expériences, ou bien avant chaque journée d'expériences, suivant le cas.

Les vitesses de propagation des premières ondulations des fronts d'onde ont été enregistrées à l'aide d'un ensemble de relais contacteurs, louverture et la fermeture des circuits étant déclenchées par l'onde elle-même. L'intervalle de temps séparant l'établissement et la rupture du circuit élait enregistré au moyen d'un chronographe à plume.

L'examen des fronts d'onde se propageant le long du canal a mis en évidence que, pour un débit initial donné, les amplitudes des ondulations successives augmentaient, atteignaient une valeur maximale, et ensuite, diminuaient proprogressivement. Au contraire, aux débits relativement peu élevés, les ondulations atteignaient une hauteur limite, et ensuite, déferlaient aux parois, ainsi qu'on avail pu le supposer; l'étendue de ce déferlement, vers l'intérieur du canal, dépendait, également, de l'importance du débit. Un autre aspect intéressant du phénomène était la manière dont variait la hauteur de crête des ondulations à travers le canal : cette hauleur était plus importante au voisinage des parois, là où la profondeur d'eau variait rapidement.

Nous avons également pu constater que, dès le déferlement de l'onde aux parois, la crête apparaissait, dans le plan horizontal, sous la forme d'une ligne droite, dont les extrémites étaient recourbées en arant; au contraire aux faibles débits (c'est-à-dire sans déferlement des ondes latérales), elle présentait une forme courbe.

Enfin la comparaison de ces ondes avec celles engendrées dans des canaux rectangulaires fait ressortir une différence importante : les ondes secondaires en «queue de poisson» ne sont engendrées que dans les canaux prismatiques. A notre avis, elles seraient provoquées par l'écoulement transversal qui se produit lorsque la hauteur d'eau varie rapidement dans un canal prismatique. Lorsque les parois d'un tel canal sont très inclinées par rapport a la verticale, ces ondes secondaires arrivent à masquer complètement les ondes primaires. 


\section{RESULTATS EXPERIMENTAUX}

Des enregistrements complets ont été obtenus pour les profils de chaque onde étudiece, mais nous avons seulement extrait un nombre limité de valeurs de ces enregistrements, notamment celles des hauteurs de la première crête d'onde, et du premier creux, au-dessus du fond du canal, de la première longueur d'onde, et de la célérité de l'onde.

Les enregistrements ont été effectués aux stations de mesure $n^{\circ s} 2$ et 4 , lesquelles étaient situées respectivement, à 24 pieds, $(7,31 \mathrm{~m})$ et à 48 pieds, $(14,63 \mathrm{~m})$ de l'entrée du canal. La hauteur d'eau était de 3 pouces, $(76 \mathrm{~mm})$ pour toutes les expériences.

La figure 8 a représente les profondeurs à la première crête, et au premier creux, en fonction du débit, dans un canal rectangulaire, $\left(\theta=0^{\circ}\right)$, aux stations de mesure $n^{\text {os }} 2$ et 4 . Les courbes sont lisses et régulières jusqu'au déferlement de la première crète. Au débit correspondant, le phénomène déjà signalé de la formation renouvelée de l'onde, après son déferlement, reconstituant une onde lisse et ondulée, est mis en ćvidence par l'enregistrement obtenu à la station $n^{*} 4$, et par la confrontation des enregistrements obtenus aux deux stations de mesure. A la station $\mathrm{n}^{\circ} 4$ (à laquelle les ondulations de front d'onde sont enlièrement établies) la relation est manifestement linéaire, entre la hauteur de crête et le débit, tant que les ondes n'ont pas déferlé.

Les figures $\mathrm{n}^{\text {os }} 8 \mathrm{~b}, 8 \mathrm{c}$ et $8 d$ représentent des conditions semblables, à la station $n^{\circ} 4$, pour $0=30^{\circ}, 45^{\circ}$ et $60^{\circ}$. Les amplitudes maximales sont inférieures à celles de la figure $8 \alpha$, mais ne présentent aucune discontinuité brusque, telle que celles caractérisant les enregistrements obtenus pour les canaux rectangulaires. Des enregistrements séparés ont été effectués en divers points répartis sur la section transversale du canal; ces positions sont indiquées sur la figure. La relation entre l'amplitude d'onde maximale et le débit initial, est manifestement linéaire, tant que les ondes latérales n'ont pas déferlé.

Les figures $9 a, 9 b$ et $9 c$ présentent une image plus «parlante», puisqu'elles indiquent les profils transversaux de la première crête à la section $\mathrm{n}^{\circ} 4$, pour des incréments de débit, et pour des valeurs de $\theta=30^{\circ}, 45^{\circ}$ et $60^{\circ}$. Lorsque $0=30^{\circ}$, la courbure change très nettement, à la verticale de la jonction du fond et des parois du canal. Cette variation de la courbure disparait lorsque le débit est suffisamment élevé pour que les ondes latérales déferlent; aux débits beaucoup plus importants, la courbure se ren- verse. Ces variations de la courbure, avant le déferlement des ondes latérales, sont beaucoup moins nettes lorsque $\theta=45^{\circ}$, mais les profils sont alors moins réguliers après le déferlement. Les variations de courbure sont encore moins apparentes pour $\theta=60^{\circ}$, puisque le régime est tel que le canal devient, dans ces conditions, presque comparable à un canal rectangulaire beaucoup plus large.

Lors des premiers essais, dans un canal rectangulaire, des résultats complémentaires ont été obtenus en prévoyant, sur les parois, une rugosité artificielle au moyen de fil de fer en «cage à poule». Lorsque la profondeur d'eau maximale a été portée en fonction du débit, sous forme adimensionnelle, l'influence de la rugosité se voyait très nettement, mais elle a masqué toute ressemblance entre les diverses amplitudes d'onde. Les résultats ont, par conséquent, été présentés sous une corme différente (fig. 10), avec, cette fois, $\eta_{\text {crete }} / \eta_{0}$ en fonction de $c / \sqrt{g_{10}}, c$ étant la célérité du front d'onde, et icrete étant la hauteur d'eau au-dessus de l'axe du canal. Il apparaît une corrélation, lorsque $0=0^{\circ}$, puisque la rusosité paraît n'exercer qu'une faible influence sur l'amplitude de la première onde. Ce résultat n'est pas tout à fait inattendu, puisque Seott Russell \% et Airey [1] avaient déjà démontré qu'en eau peu profonde, et pour un écoulement plan, l'amplitude d'onde est presque entièrement fonction de la hauteur d'écoulement.

Le résultat empirique obtenu par Scott Russell :

$$
c=\sqrt{g r_{\max }}
$$

a étẻ vérifié an cours des premières expériences, et on a pu constater que les écarts entre les valeurs mesurées et calculées pour $c$ étaient très faibles.

Cependant, l'examen des résultats obtenus pour le canal prismatique met en évidence des différences prononcées entre les valeurs mesurées et les valeurs théoriques, et montre que, pour des faibles valeurs du débit initial, les valeurs de $c / \sqrt{g \eta_{0}}$ sont inférieures $\dot{\alpha}$ l'unité. La raison en est que la profondeur d'eau moyenne, dans le canal, est inférieure à la profondeur d'eau maximale et que, par conséquent, la célérité moyeme des fronts d'onde sera inférieure à celle correspondant, pour un écoulement plan, à la profondeur d'eau maximale. Les résultats ont donc été reportés en abaque dans la figure 10, avec $\eta_{\text {crete }} / \eta_{0}$ en fonction de $c / \sqrt{g m}, m$ étant le 
rayon hydraulique moyen par rapport à $\eta_{\text {trete }}$.

Il subsiste cependant manifestement une différence considérable entre les résultats mesurés et les valeurs calculées, malgré la ressemblance entre les formes générales des résultats correspondant aux différentes inclinaisons des parois. Ceci permet de conclure que ces variations doivent découler du profil du canal, puisque, comme nous l'avons déjà vu, le frottement n'exerce qu'une très faible influence (ou mème aucune) sur l'amplitude de la première onde.

L'examen de la figure 10 montre également que, dans un canal rectangulaire, le frottement affecte très nettement la profondeur du creux. De même, elle permet de mettre en évidence l'influence appréciable de la rugosité sur les longueurs d'onde des ondulations.

\section{CONFRONTATION DES RESULTATS THEORIQUES AVEC LES RESULTATS EXPERIMENTAUX}

Cette comparaison est présentée dans la figure 11 . On voit que la concordance des résultats est bonne pour un canal rectangulaire. Lorsque $\theta=30^{\circ}$ et $45^{\circ}$, la profondeur théorique à la première crête est légèrement inférieure à la profondeur de la crête, à la paroi, mais plus grande que celle au droit de l'axe du canal. Cependant, la confrontation des longueurs d'onde et des profondeurs des deuxièmes crêtes montre que la corrélation est bien meilleure pour ces inclinaisons des parois.
Lorsque $0=60^{\circ}$, les résultats calculés sont presque les mêmes que les valeurs maximales expérimentales correspondant à la première et à la deuxième crête, mais les longueurs d'onde sont très diflérentes.

Soulignons, enfin, que les conditions expérimentales ont été choisies telles que le débit était inférieur à la valeur nécessaire pour provoquer le déferlement des ondes latérales.

\section{CONCLUSIONS}

La forme des ondulations de front d'onde dépend évidemment, à la fois, de la rugosité du canal, et de sa forme. Les analyses théoriques effectuées par Serre, et par d'autres auteurs, pour les canaux rectangulaires paraissent être justifiées, bien qu'aucune tentative d'analyse de la propagation des ondulations de front d'onde dans les canaux prismatiques n'ait été faite précédemment.

Bien que la présente analyse ne soit nécessairement qu'une approximation, et bien que les profils calculés ne s'accordent pas entièrement. avec les résultats expérimentaux, ils présentent néanmoins une certaine valeur, puisqu'ils indiquent l'amplitude maximale de la crête d'onde, tant que les ondes latérales n'ont pas déferlé. L'écart maximal, dans le cas le plus défavorable, est inférieur à $10 \%$; pour le cas où les ondes latérales ont déferlé, l'amplitude maximale calculée sera supérieure à l'amplitude réelle. L'aspect le plus intéressant ressortant de cette étude était la variation considérable des hauteurs de crête à travers la section du canal; dans des conditions réclles, celle variation exigerait des hauteurs d'écoulement maximales possibles beaucoup plus grandes que la hauteur moyenne. Notons, toutefois, que l'amplitude d'onde maximale est toujours moins importante lorsque le front d'onde se propage dans un canal de section prismatique, en raison de la perte d'énergie considérable se produisant lors du déferlement de l'onde latérale.

L'étude décrite a ćté effectuée dans les laboratoires techniques de l'University College à Swansea. Les auteurs remercient le Departement of Scientific and Industrial Research, qui a financé l'achat des appareils et de l'installation employés, et la Standard Telephones and Cables Company, Ltd., pour la mise à disposition d'une calculatrice électronique, et pour l'aide apportée lors de l'établissement des programmes de calcul. 